\title{
Comparison of the meteorology and surface energy balance at Storbreen and Midtdalsbreen, two glaciers in southern Norway
}

\author{
R. H. Giesen ${ }^{1}$, L. M. Andreassen ${ }^{2,3}$, M. R. van den Broeke ${ }^{1}$, and J. Oerlemans ${ }^{1}$ \\ ${ }^{1}$ Institute for Marine and Atmospheric research Utrecht, Utrecht University, Princetonplein 5, 3584 CC \\ Utrecht, The Netherlands \\ ${ }^{2}$ Section for Glaciers, Snow and Ice, Norwegian Water Resources and Energy Directorate, P.O. Box 5091 Majorstua, 0316 \\ Oslo, Norway \\ ${ }^{3}$ Department of Geosciences, University of Oslo, P.O. Box 1047 Blindern, 0316 Oslo, Norway
}

Received: 13 October 2008 - Published in The Cryosphere Discuss.: 17 December 2008

Revised: 5 March 2009 - Accepted: 11 March 2009 - Published: 20 March 2009

\begin{abstract}
We compare 5 years of meteorological records from automatic weather stations (AWSs) on Storbreen and Midtdalsbreen, two glaciers in southern Norway, located approximately $120 \mathrm{~km}$ apart. The records are obtained from identical AWSs with an altitude difference of $120 \mathrm{~m}$ and cover the period September 2001 to September 2006. Air temperature at the AWS locations is found to be highly correlated, even with the seasonal cycle removed. The most striking difference between the two sites is the difference in wind climate. Midtdalsbreen is much more under influence of the large-scale circulation with wind speeds on average a factor 1.75 higher. On Storbreen, weaker katabatic winds are dominant. The main melt season is from May to September at both locations. During the melt season, incoming and net solar radiation are larger on Midtdalsbreen, whereas incoming and net longwave radiation are larger on Storbreen, primarily caused by thicker clouds on the latter. The turbulent fluxes are a factor 1.7 larger on Midtdalsbreen, mainly due to the higher wind speeds. Inter-daily fluctuations in the surface energy fluxes are very similar at the AWS sites. On average, melt energy is a factor 1.3 larger on Midtdalsbreen, a result of both larger net radiation and larger turbulent fluxes. The relative contribution of net radiation to surface melt is larger on Storbreen (76\%) than on Midtdalsbreen (66\%). As winter snow depth at the two locations is comparable in most years, the larger amount of melt energy results in an earlier disappearance of the snowpack on Midtdalsbreen and 70\% more ice melt than on Storbreen. We compare the relative and absolute values of the energy fluxes on Storbreen and Midtdalsbreen with reported values for glaciers at similar
\end{abstract}

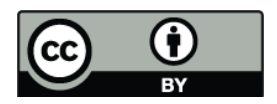

Correspondence to: R. H. Giesen (r.h.giesen@uu.nl) latitudes. Furthermore, a comparison is made with meteorological variables measured at two nearby weather stations, showing that on-site measurements are essential for an accurate calculation of the surface energy balance and melt rate.

\section{Introduction}

The climate in southern Norway shows a strong precipitation gradient from west to east, with a maritime climate at the western coast and a more continental climate east of the main watershed, located less than $150 \mathrm{~km}$ from the coast (Fig. 1, Green and Harding, 1980). The glaciers of southern Norway are found in the areas with the largest annual snow amount; areas characterized by a combination of low temperatures due to topography and sufficient precipitation (Figs. 1 and 2). The annual mass balance turnover (the summed absolute values of the area-averaged winter and summer balance divided by two) on glaciers in southern Norway reflects the precipitation gradient, ranging from $3.7 \mathrm{~m}$ water equivalent (w.e.) at Ålfotbreen near the coast to $0.92 \mathrm{~m}$ w.e. on Gråsubreen in eastern Jotunheimen, further inland. On Ålfotbreen, interannual fluctuations in the net mass balance are primarily determined by variations in the winter balance, while summer-balance variations dominate interannual variability at the more continental glaciers (Andreassen et al., 2005).

Climate maps reveal large-scale patterns in meteorological variables, giving a first indication where conditions are favourable for glaciers. At smaller spatial scales, large deviations from these numbers occur due to differences in the altitude and terrain exposure. Accumulation and ablation on glaciers are not only related to the local air temperature and winter precipitation, but are also influenced by other

Published by Copernicus Publications on behalf of the European Geosciences Union. 
Normal annual temperature
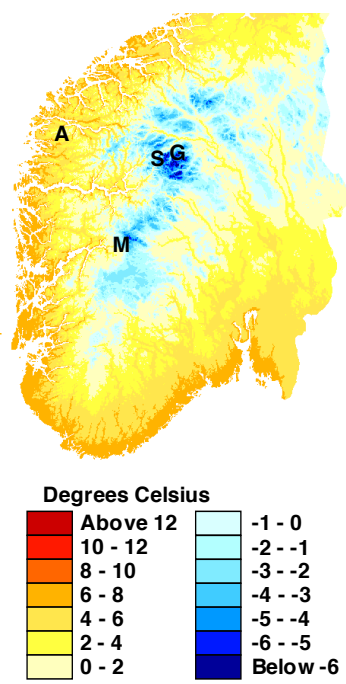

Normal annual precipitation

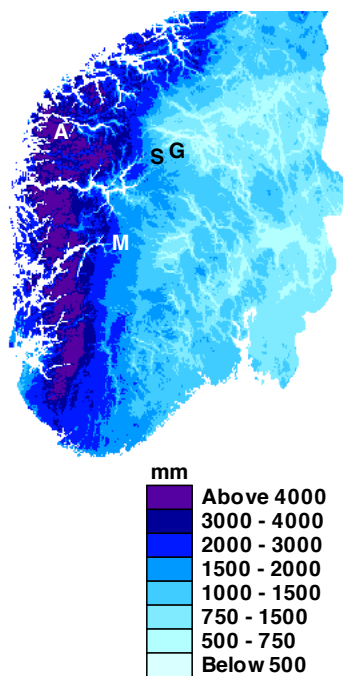

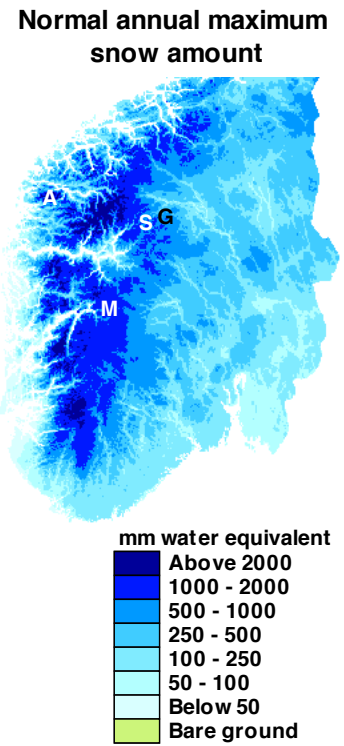

Fig. 1. Annual mean air temperature, precipitation and maximum snow amount in southern Norway over the normal period 1971-2000. Note the non-linear scale. The maps are downloaded from seNorge.no, an initiative of the Norwegian Meteorological Institute, the Norwegian Water Resources and Energy Directorate and the Norwegian Mapping Authority. The locations of Storbreen (S), Midtdalsbreen (M), Ålfotbreen (A) and Gråsubreen $(\mathrm{G})$ are indicated on each map.

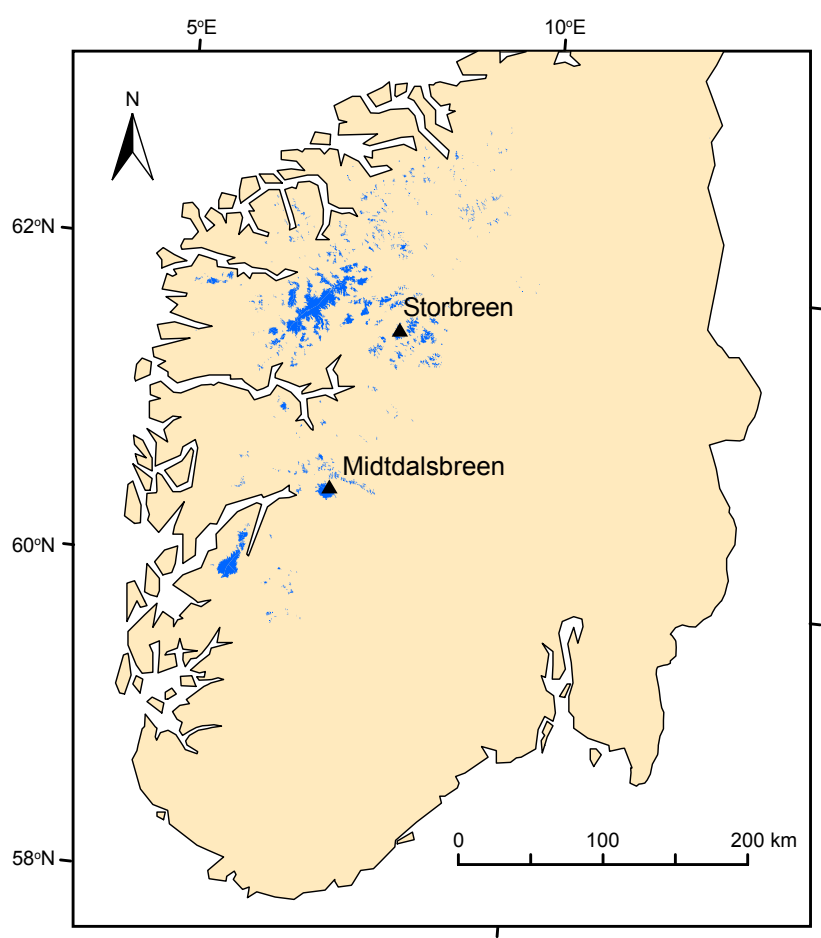

Fig. 2. Glaciers in southern Norway (in blue) and the location of Storbreen and Midtdalsbreen. The source for this map is the Statens Kartverk 1:250 000 map series and includes perennial snow fields. variables and factors, for example wind speed, cloudiness and surface properties. Therefore, detailed knowledge of the relation between meteorological quantities and the mass and energy exchange at the glacier surface can only be obtained from meteorological studies on glaciers. Between 1954 and 1981, glacio-meteorological experiments have been carried out on a number of glaciers in southern Norway (e.g., Liestøl, 1967; Klemsdal, 1970; Messel, 1971). The combined results from these studies reveal that the relative importance of radiative fluxes compared to turbulent fluxes for surface melt increases from glaciers near the coast to the glaciers further inland (Messel, 1985). However, a detailed comparison could not be made as the studies were conducted in different years and for different periods during the summer season.

In this paper, we compare meteorological records from two identical AWSs on Midtdalsbreen and Storbreen, two glaciers in southern Norway, $120 \mathrm{~km}$ apart (Fig. 2). Both glaciers are located in the transitional zone between the maritime climate at the coast and the more continental inland climate. We use meteorological data collected over 5 years, from September 2001 until September 2006. The AWS data sets comprise all quantities needed to determine the atmospheric energy fluxes, including the four radiation fluxes. Apart from a 19-day data gap in the summer of 2004 for Storbreen and a 39-day gap in the Midtdalsbreen record for the summer of 2005, the records are continuous. Analyses of the time series have shed light on the local meteorology and the surface energy and mass balance at the AWS sites (Andreassen et al., 2008; Giesen et al., 2008). Here, we analyse similarities and differences between meteorological variables 
Table 1. The main characteristics of Storbreen and Midtdalsbreen and the AWS sites on the two glaciers. Values are derived from a digital terrain model (DTM) for Storbreen from 1997 (Andreassen, 1999) and a DTM for Hardangerjøkulen from 1995 derived from the $25 \mathrm{~m}$ resolution digital terrain model (DTM25) of Norway by the Norwegian mapping authorities (Statens Kartverk, http://www. statkart.no).

\begin{tabular}{lrr}
\hline & Storbreen & Midtdalsbreen \\
\hline General characteristics & & \\
Latitude $\left({ }^{\circ} \mathrm{N}\right)$ & 61.60 & 60.57 \\
Longitude $\left({ }^{\circ} \mathrm{E}\right)$ & 8.13 & 7.47 \\
Area $\left(\mathrm{km}^{2}\right)$ & 5.4 & 6.7 \\
Lowest altitude (m a.s.1.) & 1390 & 1380 \\
Highest altitude (m a.s.1.) & 2090 & 1865 \\
AWS location & & \\
Altitude (m a.s.1.) & 1570 & 1450 \\
Distance from the snout $(\mathrm{m})$ & 900 & 400 \\
Surface slope $\left(^{\circ}\right)$ & 6 & 7 \\
Surface aspect & $\mathrm{NE}$ & $\mathrm{NE}$ \\
\hline
\end{tabular}

measured on the two glaciers and discuss their influence on the surface energy balance. In line with previous studies we compare the relative contribution of the surface energy fluxes to melt. The absolute and relative values of the surface energy fluxes are compared with values found for glaciers at similar latitudes, for which we provide a summary which complements earlier overviews (e.g., Ohmura, 2001; Willis et al., 2002; Hock, 2005). To investigate whether similarities and differences found for meteorological variables on Storbreen and Midtdalsbreen are also observed outside the glacier boundary-layer, we compare our data with records from two nearby weather stations.

\section{Setting and AWS description}

Storbreen and Midtdalsbreen are located in southern Norway, $120 \mathrm{~km}$ apart (Figs. 2 and 3). Storbreen is a valley glacier in the western part of the Jotunheimen mountain massif. Midtdalsbreen is an outlet glacier of Hardangerjøkulen, an ice cap situated at the north-western border of the Hardangervidda plateau. Both glaciers are facing north-east, cover a similar altitudinal range and are of comparable size (Table 1). Storbreen has had a mass deficit since annual mass balance measurements started in 1949 (Andreassen et al., 2005). No longterm mass balance series are available for Midtdalsbreen, but annual measurements were initiated in 1963 on Rembesdalsskåka, another outlet glacier from Hardangerjøkulen. They show an approximate equilibrium until the late 1980s and a subsequent mass surplus. After 2000, net mass balances were mainly negative; the net balance of the year 2006 was the lowest ever measured on both Storbreen and Rembesdalsskåka (Kjøllmoen et al., 2007). The net retreat over the period 1982-2006, when length change was measured at both glaciers, was $80 \mathrm{~m}$ at Storbreen and $25 \mathrm{~m}$ at Midtdalsbreen.

The AWSs on Midtdalsbreen and Storbreen (Fig. 3) are operated by the Institute of Marine and Atmospheric research Utrecht (IMAU). The AWS on Midtdalsbreen was placed in October 2000, the AWS on Storbreen in September 2001. The stations are of identical design and are both located in the ablation zones of the respective glaciers. The mast rests on the ice surface. Air temperature and humidity, wind speed and wind direction are measured at two levels. Temperature and humidity sensors (Vaisala HMP45C) are mounted on the arms at approximately 2.4 and $5.7 \mathrm{~m}$ above the ice surface, the measurement level of the wind speed and wind direction sensors (Young 05103) is $0.35 \mathrm{~m}$ higher. In addition, the upper arm carries a radiation sensor (Kipp \& Zonen CNR1), measuring the four components of the radiation balance (incoming and reflected solar radiation, incoming and outgoing longwave radiation), and a sonic ranger (Campbell SR50), measuring the distance to the surface. A second sonic ranger is mounted on a tripod, which is drilled into the ice (Fig. 3). This sonic ranger registers both ice melt and snow accumulation. The sonic ranger in the mast ensures a continuous record when the other sensor is buried by snow. Readings at one to four ablation stakes around the AWS are used as a reference for the sonic ranger measurements and enable continuation of the surface height record when data from the sonic rangers is missing. Air pressure (Vaisala PTB101B) is recorded inside the box containing the electronics. Sample time varies per sensor, every $30 \mathrm{~min}$ (average) values are stored on a data logger (Campbell CR10X). Power is supplied by lithium batteries, the solar panel generates energy to ventilate the temperature sensors.

\section{Methods}

\subsection{Data treatment}

In this section we give an overview of the necessary corrections to the data. More detailed descriptions are given in Andreassen et al. (2008) and Giesen et al. (2008).

- Air temperature was corrected for radiation errors at times when the sensor was not aspirated using expressions that give the excess temperature as a function of wind speed and the sum of incoming and reflected solar radiation.

- Relative humidity measured at temperatures below the melting point was corrected by multiplying with the ratio of the saturated water vapour pressures over water and over ice, using an expression by Curry and Webster (1999). Specific humidity has been calculated from the measurements of relative humidity, air temperature and air pressure. 

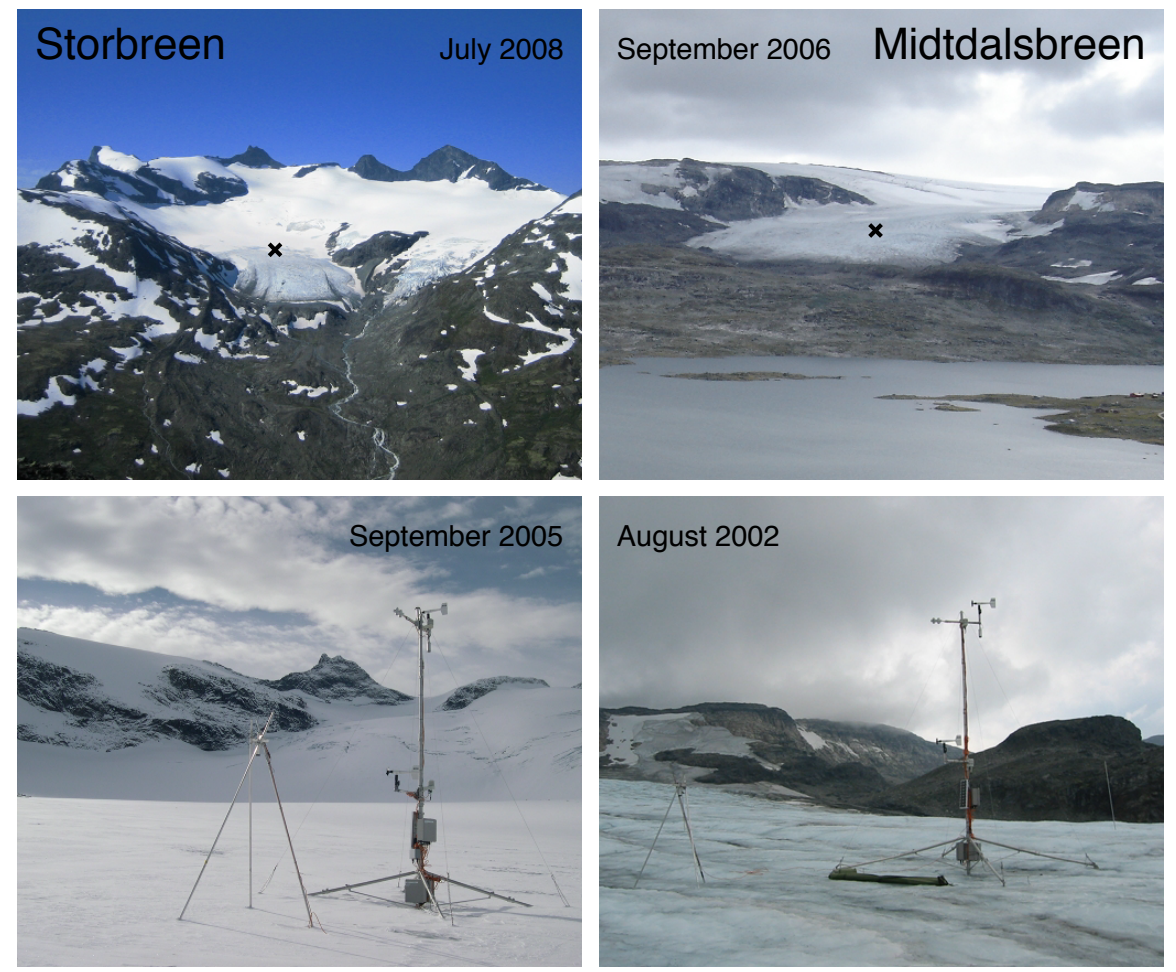

Fig. 3. The location of the AWSs $(\times)$ on Storbreen (left) and Midtdalsbreen (right) and a close-up of the AWS sites. The tripod with a sonic ranger is seen to the left of the mast.

- The sonic ranger uses the speed of sound at $0^{\circ} \mathrm{C}$ to determine the distance to the surface. As the speed of sound is a function of air density and hence temperature, the record was corrected by multiplying with the ratio of the actual speed of sound and the speed of sound at $0^{\circ} \mathrm{C}$.

- The tilt of the masts was estimated from tilt angles measured during maintenance visits, combined with data from a tilt sensor in the mast, which did not function properly. On Midtdalsbreen the estimated tilt of the mast is often large enough to significantly affect the absolute value of the incoming solar radiation. The tilt only affects the direct solar beam, hence we applied a tilt correction dependent on cloudiness. A tilted mast also influences the reflected solar radiation measurements, but the correction was found to be smaller than uncertainties associated with the poor tilt estimates and was therefore not applied. Tilt values recorded on Storbreen are smaller and do not seem to influence daily mean values of incoming solar radiation significantly. Hence, no tilt correction was applied to the incoming solar radiation on Storbreen.

- Half-hourly values of net shortwave radiation were calculated using the accumulated albedo method (Van den Broeke et al., 2004) to remove the effects of a poor cosine response of the radiation sensor at low sun angles and a possible phase shift due to tilting of the sensor on the daily cycle of incoming solar radiation. As we only use daily averaged values in this analysis, the effect of this correction on net shortwave radiation is negligible.

- Due to the opening of a crevasse, the mast on Storbreen fell down in the summer of 2004. The same happened on Midtdalsbreen in 2005. As the data measured during these periods cannot be used in the analysis, the series from Storbreen contains a 19-day gap from 30 July to 17 August 2004. The series from Midtdalsbreen has 39 days without useful data from 18 July to 25 August 2005. Motivated by the observation that the records of all variables on Storbreen and Midtdalsbreen generally display similar and simultaneous fluctuations, we used measurements from Midtdalsbreen to create a data set to fill the gap on Storbreen. For the data gap on Midtdalsbreen, we used measurements from an AWS at the summit of Hardangerjøkulen, except for relative humidity and incoming longwave radiation where data from Storbreen were used.

- The sonic rangers on the tripods were buried by the snowpack during several winter seasons and melted out at the end of several summer periods. In addition to this, sonic ranger data are missing for shorter periods during the rest of the year, for various reasons. Small gaps in the surface height record were filled by linear interpolation between surrounding values, for larger gaps in 
the melt season we used melt values calculated from the surface energy balance, combined with stake readings. For Storbreen, measurements from both sonic rangers are lacking during the accumulation season of 2002 2003. For this period, precipitation data from the nearby Norwegian Meteorological Institute (NMI) weather station Bråtå (664 m a.s.l.) were used to create a continuous record.

\subsection{Cloud fraction and effective cloud optical depth}

Information about clouds can be obtained from both incoming shortwave and incoming longwave radiation. Fractional cloud cover was estimated from incoming longwave radiation (Van den Broeke et al., 2008a). Cloud optical thickness was determined from incoming solar radiation using an expression by Fitzpatrick et al. (2004), resulting in effective cloud optical depth values representative for a uniform cloud cover consisting of cloud droplets with a standard effective radius of $8.6 \mu \mathrm{m}$. However, this expression can only be applied to daytime measurements without shading by the topography. For all days with more than 20 half-hourly values for the cloud optical thickness, we calculated daily averages and regressed these values against the cloud fraction. For both locations, an exponential function fitted the data well (linear correlation $r$ of 0.81 ) and was used to obtain yearround daily values for cloud optical depth.

\subsection{Surface energy balance}

The energy balance at the glacier surface can be described by

$$
\begin{aligned}
Q & =S_{\text {in }}+S_{\text {out }}+L_{\text {in }}+L_{\text {out }}+H_{\text {sen }}+H_{\text {lat }}+G \\
& =S_{\text {net }}+L_{\text {net }}+H_{\text {sen }}+H_{\text {lat }}+G,
\end{aligned}
$$

where $Q$ is melt energy ( $Q=0$ if the surface temperature is below the melting point), $S_{\text {in }}$ and $S_{\text {out }}$ are incoming and reflected solar radiation, $L_{\text {in }}$ and $L_{\text {out }}$ are incoming and outgoing longwave radiation, $H_{\text {sen }}$ and $H_{\text {lat }}$ are the sensible and latent heat fluxes and $G$ is the subsurface heat flux. Net solar radiation and net longwave radiation are written as $S_{\text {net }}$ and $L_{\text {net }}$. All fluxes are defined positive when directed towards the surface. Heat supplied by rain is neglected, which is justified on glaciers with a considerable mass turnover (Oerlemans, 2001). Penetration of shortwave radiation is not included either. Compared to the other fluxes its contribution to the energy balance is expected to be small and it has been shown not to affect total melt (Van den Broeke et al., 2008b).

\subsubsection{Model description}

We have used an energy balance model that solves Eq. (1) for a skin layer without heat capacity, which is described in more detail by Van den Broeke et al. $(2005,2006)$. $S_{\text {in }}$, $S_{\text {out }}$ and $L_{\text {in }}$ are taken from the (corrected) measurements, the other fluxes are written as functions of the surface temperature $T_{\mathrm{s}}$. The model time-step is $10 \mathrm{~min}$, to obtain model input for every time-step, the AWS data are linearly interpolated between half-hourly values. Using an iterative procedure, the surface energy balance is solved for the surface temperature $T_{\mathrm{s}}$. If $T_{\mathrm{s}}$ found by the model is higher than the melting point temperature, $T_{\mathrm{s}}$ is set back to $0^{\circ} \mathrm{C}$ and the excess energy is used for melting. The amount of melt $M$ in meters water equivalent (m w.e.) is calculated by dividing $Q$ by the latent heat of fusion $\left(3.34 \times 10^{5} \mathrm{~J} \mathrm{~kg}^{-1}\right)$ and the density of water $\left(1000 \mathrm{~kg} \mathrm{~m}^{-3}\right)$.

The turbulent fluxes are computed with the bulk method, based on differences in temperature, humidity and wind speed between the measurement level and the surface. We use measurements from the upper level, the records from the lower level sensors contain several data gaps. Following Van den Broeke et al. (2005), stability correction functions by Holtslag and De Bruin (1988) and Dyer (1974) are applied for stable and unstable conditions, respectively. A comparison of turbulent fluxes calculated with data from either the upper or the lower measurement level revealed that when using wind speed measurements from the upper level, turbulent fluxes are underestimated, mainly on days with low wind speeds. At both AWS sites, the ratio of wind speeds measured at the upper and lower level is always larger than unity for wind speeds above $6 \mathrm{~m} \mathrm{~s}^{-1}$; for lower wind speeds this ratio is smaller than unity about $20 \%$ of the time. On days with a wind speed maximum below the upper level, the wind is always directed down-slope. Moreover, the temperature difference between the air and the surface is mostly larger than $5 \mathrm{~K}$, suggesting the presence of katabatically driven flow. Although wind speeds are relatively low in these circumstances, turbulent fluxes are underestimated considerably by using the upper level measurements, because the temperature difference between the air and the surface is large. To obtain good agreement between turbulent fluxes calculated with the upper or lower level measurements, we limited the turbulent flux reduction by the stability correction to one third when using the upper level data. For the surface roughness length for momentum $\left(z_{0 v}\right)$ we use constant values of $0.13 \mathrm{~mm}$ for snow surfaces and $0.75 \mathrm{~mm}$ for ice surfaces at both AWS sites. Whether the surface is ice or snow is determined from a snow depth record constructed from the sonic ranger measurements. The roughness length values are median values, derived from wind speed differences between the AWS upper and lower measurement levels at near-neutral atmospheric conditions. We used the derived roughness lengths for Midtdalsbreen, as only few datapoints remained for near-neutral conditions at Storbreen and these were mainly found in midwinter, biasing $z_{0 v}$ towards low values. Using roughness lengths from Midtdalsbreen on Storbreen will not likely introduce a large error, because derived values are similar during the periods they could be calculated for both glaciers and the surface characteristics at the AWS sites are comparable. Sensitivity tests with the energy balance model using data 

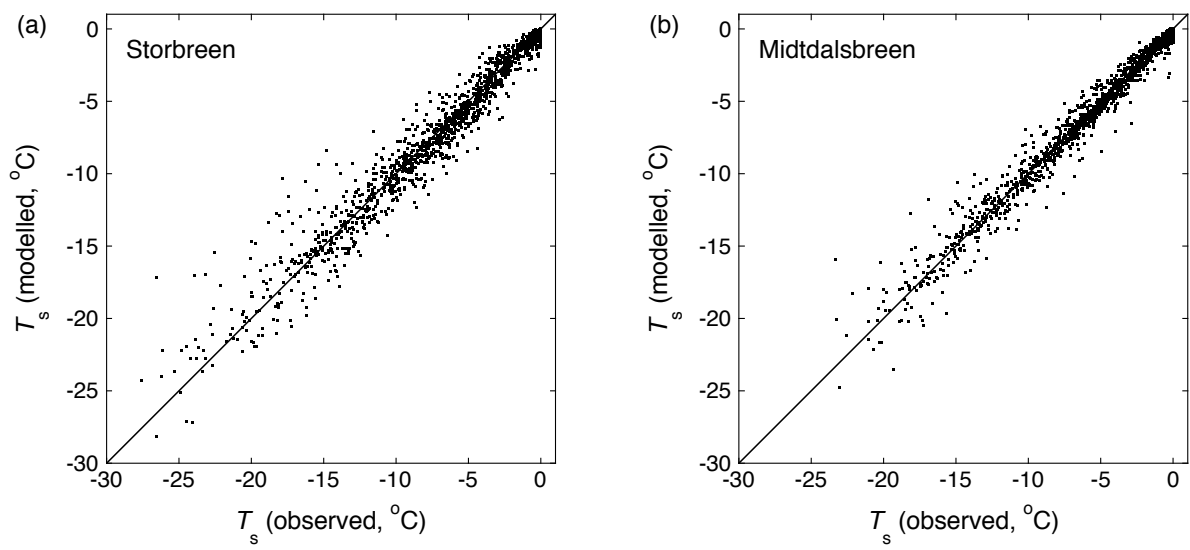

Fig. 4. Modelled versus observed surface temperature (daily mean values) for (a) Storbreen and (b) Midtdalsbreen.

from Midtdalsbreen, have shown that an order-of-magnitude change in $z_{0 v}$ roughly affects the sum of the turbulent fluxes by $15 \%$, while removing the stability correction increases the summed turbulent fluxes by $20 \%$, on average (Giesen et al., 2008). The roughness lengths for heat and moisture are calculated from expressions by Andreas (1987).

Subsurface heat conduction is computed from the onedimensional heat-transfer equation for $0.04 \mathrm{~m}$ thick layers down to a depth of $20 \mathrm{~m}$. The temperature at the lowest level is assumed to remain stable. The initial temperature profile is generated by continuously running the model over the measurement period until the $20 \mathrm{~m}$ temperature is stable within $0.01^{\circ} \mathrm{C}$. The number of snow layers is determined by dividing the observed snow depth by the model layer thickness. Snow density has a constant value of $500 \mathrm{~kg} \mathrm{~m}^{-3}$, based on measurements in snow pits around the AWSs. Meltwater percolates vertically through the snowpack and refreezes where snow temperatures are below the melting point. When the snowpack is saturated with melt water, the remaining melt water is assumed to run off. Note that in our approach, the changing snow depth is prescribed from the sonic ranger record and not calculated by the model. This ensures that the snow cover appears and disappears at the right moment. When the snow has disappeared, input from the height sensor is not needed anymore and model and measurements are independent. For this snow-free period, the melt $M$ computed by the model can be compared with the surface lowering registered by the sonic ranger and the ablation stakes by dividing $M$ by 0.9 , the ratio of the ice and water densities used in this study.

\subsubsection{Model performance}

A comparison of the modelled and observed surface temperature (from measured $L_{\text {out }}$, assuming a surface with unit emissivity) gives an indication of the model performance. Figure 4 shows modelled versus observed daily average surface temperatures for Storbreen and Midtdalsbreen. The overall agreement is good, although surface temperatures are somewhat overestimated on clear-sky winter days. This cannot be attributed to the limited stability correction, removing the limit only slightly reduces the temperature difference on these days. Riming of the sky-facing longwave radiation sensor is a plausible cause. For Storbreen, the mean difference between modelled and observed surface temperature is $+0.07^{\circ} \mathrm{C}$, with a root-mean-square error (RMSE) of $1.3^{\circ} \mathrm{C}$. For Midtdalsbreen, the mean difference is $+0.14^{\circ} \mathrm{C}$ with a RMSE of $1.1^{\circ} \mathrm{C}$. Given the uncertainties in both the measurements and the energy balance model, this is a good result. For both locations, the match between modelled and measured surface melt is generally good (Andreassen et al., 2008; Giesen et al., 2008), which indicates that all relevant processes are included in the model and the calculated energy balance is robust.

\section{Results}

For the main atmospheric quantities and the surface energy fluxes, mean values over the five years (7 September 2001 to 6 September 2006) were computed, as well as averages over all 30-min intervals when the surface was melting $(Q>0)$. We used measurements made at the upper level for the analysis, since the records from the lower level sensors have several data gaps. Correlation coefficients $(r)$ between variables on Storbreen and Midtdalsbreen were computed for both half-hourly and daily mean values. The periods with data missing for one of the locations were excluded from the calculation of $r$. The mean values and linear correlations are listed in Table 2.

\subsection{Air temperature and humidity}

Annual mean air temperature is $0.7^{\circ} \mathrm{C}$ higher on Midtdalsbreen (Table 2), reflecting the lower altitude of the 

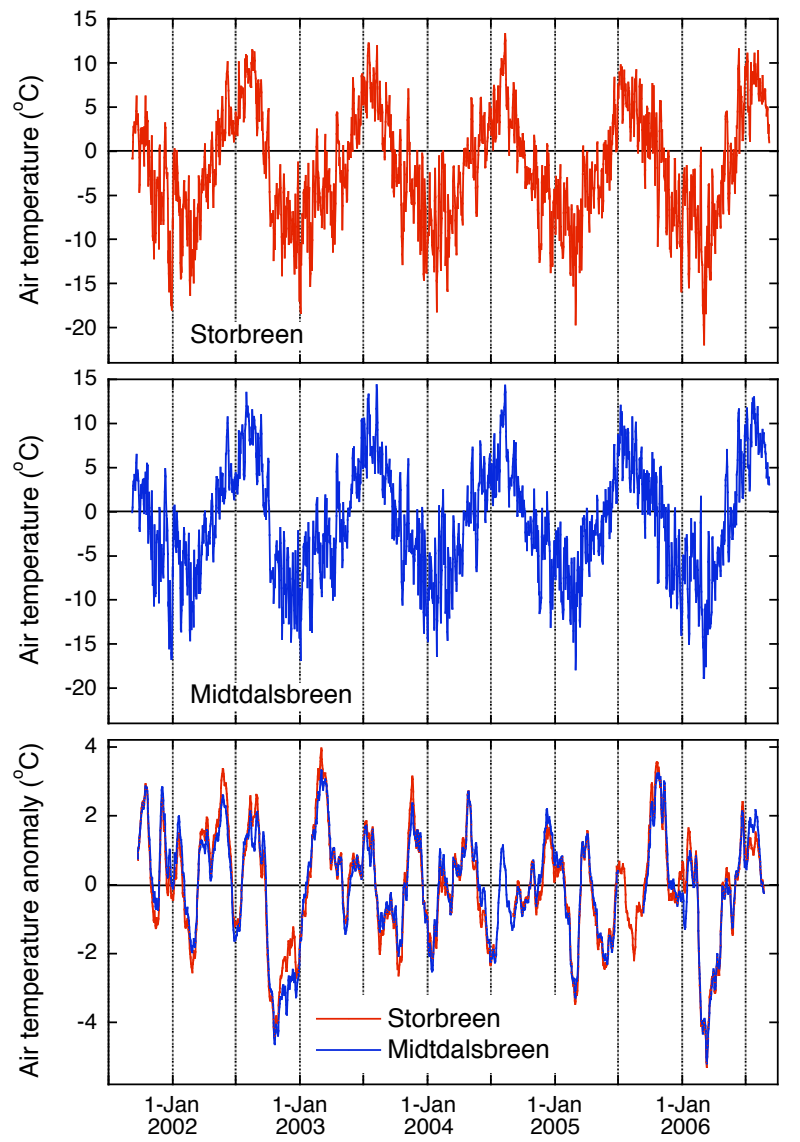

Fig. 5. Daily mean air temperature on Storbreen and Midtdalsbreen and 31-day moving average of daily air temperature anomalies on Storbreen and Midtdalsbreen. The temperature anomalies were calculated by subtracting the monthly mean temperature at both locations.

AWS location. The mean and most frequent temperature lapse rate calculated from the two temperature records is $6.0^{\circ} \mathrm{C} \mathrm{km}^{-1}$. The temperature difference is smaller during melt $\left(4.3^{\circ} \mathrm{C} \mathrm{km}^{-1}\right)$, when the air above the glaciers is cooled by the melting surface. Daily mean air temperatures for the AWS sites on Storbreen and Midtdalsbreen have an almost perfect resemblance, in both inter-daily fluctuations and annual amplitude (Fig. 5). The correlation coefficient of daily mean air temperatures on the two glaciers is 0.98 (Table 2). To eliminate the correlation due to the seasonal cycle, we calculated daily mean temperature anomalies by subtracting the monthly mean temperature, including all months with measurements available from both AWSs. After the removal of the seasonal cycle the linear correlation is still 0.95. Computed daily temperature anomalies with a moving average of 31 days, show that the winters 2000-2001, 2002-2003 and 2005-2006 were relatively cold, while the major part of the summer of 2002 was warmer than the other summers in the record (Fig. 5, third panel). In 2003, temperatures in spring were relatively high and 2005 had a very warm autumn.
At both glaciers the air is humid, with an average relative humidity around $80 \%$ (Table 2). Relative and specific humidity are generally slightly lower on Storbreen. This could indicate a more continental climate than at Midtdalsbreen, but can also be the result of a different boundary-layer structure at the two sites. As the local free-atmosphere humidity is not measured, we cannot distinguish whether the lower humidity values on Storbreen are a local or a regional feature. At both AWS sites, specific humidity averaged over the melt season is higher than the annual average, as warmer air can contain more water vapour. The mean relative humidity is also slightly higher in summer than in winter, because the free atmosphere air is cooled near the cold glacier surface, increasing the relative humidity.

\subsection{Wind speed and wind direction}

The most striking difference between the two glaciers is that wind speeds are on average 1.75 times larger on Midtdalsbreen (Table 2). This ratio is almost constant through the year, from October to December values are slightly higher. A similar ratio is found for wind speeds at the lower level, using all available simultaneous wind speed measurements from both locations. The linear correlation between wind speeds at Storbreen and Midtdalsbreen is nonetheless relatively high ( $r=0.74$ for daily means).

The dominant wind directions on the two glaciers (Fig. 6) are related to the local topography. Two wind directions are imposed by the orientation of the valleys in which the glaciers are situated. Midtdalsbreen flows into the valley Finsedalen, which has an approximate west-east orientation, seen as winds from directions $130^{\circ}$ and $280^{\circ}$. Northerly winds seldomly occur on Midtdalsbreen. Storbreen is situated in the almost north-south oriented Leirdalen, resulting in winds from $355^{\circ}$ and $165^{\circ}$. Winds with the directions $225^{\circ}$ on Midtdalsbreen and $200^{\circ}$ on Storbreen are downslope winds along the glacier length axis, commonly known as katabatic or glacier winds. Although the glacier slopes are similar (Table 1), katabatic winds occur more frequently on Storbreen and impose the dominant wind direction, while westerly winds are dominant on Midtdalsbreen. Westerly winds are also common on Storbreen and are likely largescale winds, as they generally occur simultaneously with westerly winds on Midtdalsbreen. While the highest wind speeds on Midtdalsbreen are recorded during westerly flow, westerly winds on Storbreen are much weaker. Storbreen is surrounded by higher mountains than Midtdalsbreen, which shelter the glacier from the large-scale circulation. The large differences in wind regimes suggest that on Midtdalsbreen the development of a katabatic flow is often suppressed by the strong large-scale circulation and is thereby limited to calm days, while on Storbreen katabatic winds can develop more frequently. 
Table 2. Mean values of meteorological quantities and energy fluxes for Storbreen (S) and Midtdalsbreen (M) over the period 7 September 2001-6 September 2006, for the entire period and periods when the surface was melting. The absolute accuracy is given for daily and annual mean values. Linear correlations $r$ between variables on Storbreen and Midtdalsbreen are shown for half-hourly and daily mean values.

\begin{tabular}{|c|c|c|c|c|c|c|c|c|}
\hline & \multicolumn{2}{|c|}{ Annual mean } & \multicolumn{2}{|c|}{ Melt period mean } & \multicolumn{2}{|c|}{ Accuracy } & \multicolumn{2}{|c|}{ Correlation } \\
\hline & $S$ & M & $S$ & M & day & year & $30 \mathrm{~min}$ & day \\
\hline \multicolumn{9}{|l|}{ Meteorological quantities } \\
\hline Air temperature $\left({ }^{\circ} \mathrm{C}\right)$ & -1.9 & -1.2 & 4.9 & 5.3 & 0.3 & 0.1 & 0.97 & 0.98 \\
\hline Relative humidity (\%) & 77.9 & 81.9 & 78.2 & 80.8 & 3 & 1.0 & 0.72 & 0.83 \\
\hline Specific humidity $\left(\mathrm{g} \mathrm{kg}^{-1}\right)$ & 3.4 & 3.6 & 5.1 & 5.3 & 0.2 & 0.1 & 0.95 & 0.98 \\
\hline Wind speed $\left(\mathrm{m} \mathrm{s}^{-1}\right)$ & 3.8 & 6.6 & 3.3 & 6.0 & 0.4 & 0.1 & 0.53 & 0.74 \\
\hline Air pressure (hPa) & 834.0 & 848.5 & 838.3 & 852.4 & 0.4 & 0.1 & 1.00 & 1.00 \\
\hline Cloud fraction & 0.62 & 0.60 & 0.69 & 0.64 & 0.05 & 0.02 & 0.67 & 0.83 \\
\hline Effective cloud optical depth & 16.0 & 11.9 & - & - & 10 & 3 & - & 0.72 \\
\hline Surface albedo & 0.73 & 0.68 & 0.52 & 0.47 & 0.05 & 0.02 & - & 0.91 \\
\hline \multicolumn{9}{|l|}{ Surface energy fluxes $\left(\mathrm{W} \mathrm{m}^{-2}\right)$} \\
\hline Shortwave in & 108 & 126 & 220 & 242 & 20 & 5 & 0.92 & 0.96 \\
\hline Shortwave out & -70 & -76 & -125 & -126 & 10 & 2 & 0.93 & 0.96 \\
\hline Longwave in & 272 & 270 & 311 & 304 & 10 & 2 & 0.79 & 0.91 \\
\hline Longwave out & -292 & -295 & -316 & -316 & 5 & 2 & 0.95 & 0.97 \\
\hline Sensible heat flux & 15 & 24 & 20 & 39 & 10 & 5 & 0.66 & 0.81 \\
\hline Latent heat flux & 1 & 4 & 9 & 16 & 10 & 5 & 0.75 & 0.88 \\
\hline Subsurface heat flux & 3 & 3 & -2 & -2 & 5 & 2 & 0.61 & 0.81 \\
\hline
\end{tabular}
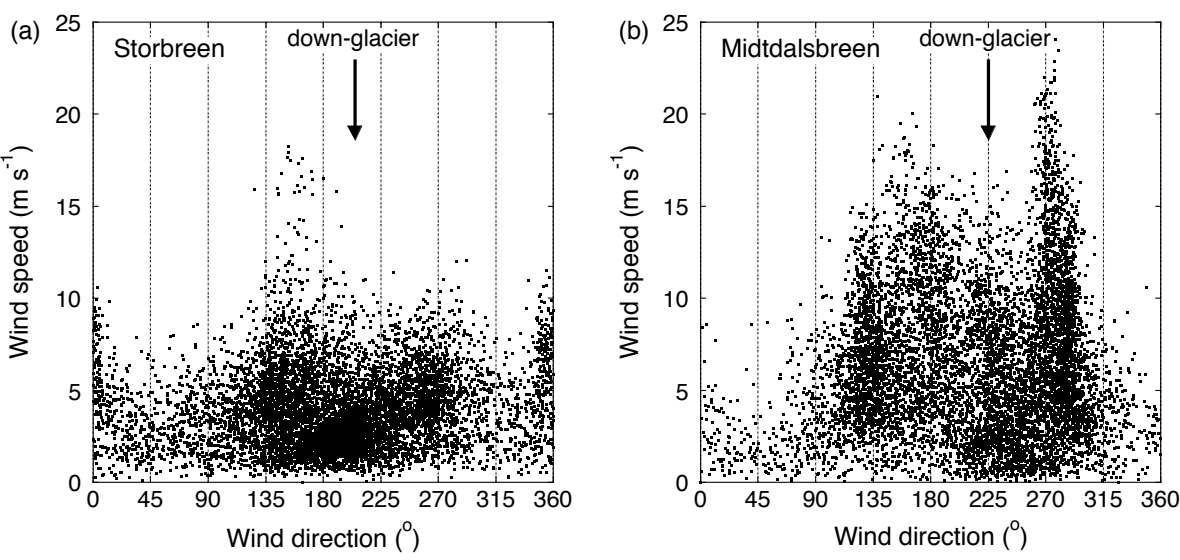

Fig. 6. Half-hourly wind speed versus wind direction on (a) Storbreen and (b) Midtdalsbreen. Measurements are shown at hourly intervals for the period September 2005 to September 2006.

\subsection{Incoming solar radiation and cloudiness}

Incoming shortwave radiation is significantly larger on Midtdalsbreen, both in the annual mean value as in periods with surface melt (Table 2). The annual mean top-ofthe-atmosphere incoming solar radiation is only $5 \mathrm{~W} \mathrm{~m}^{-2}$ higher at Midtdalsbreen, hence the lower latitude of Midtdalsbreen cannot explain this difference. Figure 7a shows that monthly mean atmospheric transmissivity at the AWS site on Midtdalsbreen is always higher than on Storbreen. On both glaciers, the atmospheric transmissivity is maximum in spring and gradually decreases during summer. The lower atmospheric transmissivity at Storbreen could be caused by more frequent shading of the AWS site or differences in cloud characteristics. In winter, shading by the surrounding topography reduces the amount of $S_{\text {in }}$ considerably, an effect which is larger on Storbreen. In summer, the solar zenith angle is much smaller and the influence of shading on $S_{\text {in }}$ is small. For this period, the cloud fraction (Table 2) and the effective cloud optical depth (Fig. 7b) are larger for Storbreen, hence the smaller $S_{\text {in }}$ in summer is mainly resulting from thicker clouds. We investigated possible relations between the difference in cloudiness and other measured variables or differences in variables between the two locations, but no dependencies were found. Since most meteorological 

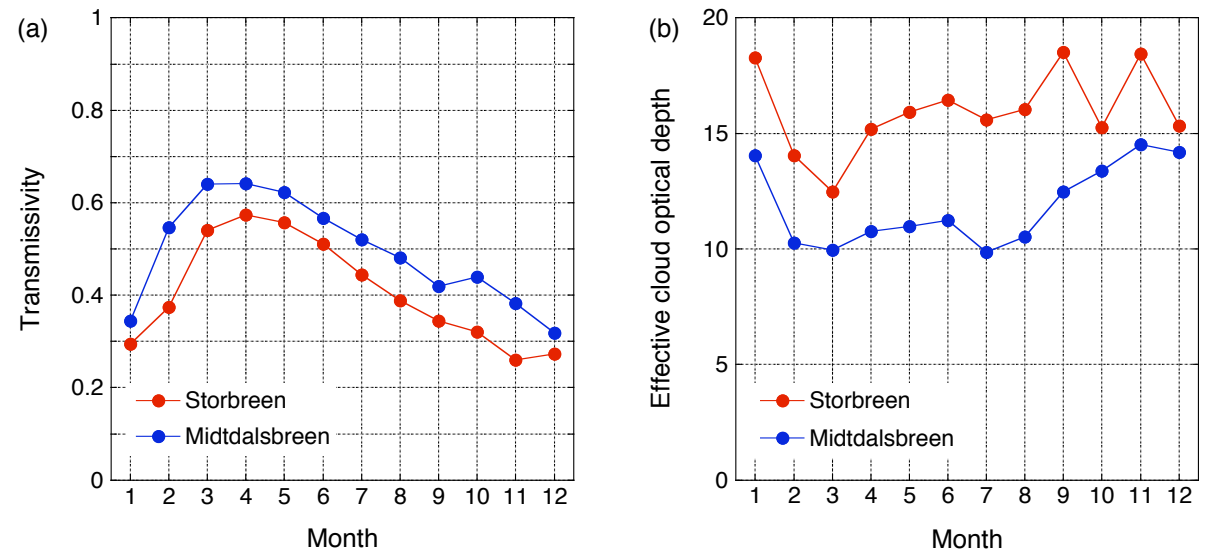

Fig. 7. Monthly mean values of (a) atmospheric transmissivity and (b) effective cloud optical depth on Storbreen and Midtdalsbreen.

variables on Storbreen and Midtdalsbreen, including $S_{\text {in }}$, are highly correlated, the larger cloud fractions found for Storbreen are likely associated with local factors affecting cloud properties and not with different synoptic situations at the two glaciers.

\subsection{Reflected shortwave radiation and surface albedo}

Figure 8 presents the daily mean surface albedo for Storbreen and Midtdalsbreen for two winter and summer seasons. These years were selected because the data are continuous and cover two complete seasons. Snow generally starts to accumulate at the AWS sites between the end of September and the end of October. The albedo fluctuations in winter are very similar on the two glaciers. In summer, most precipitation falls as rain at the AWS sites, but occasional snowfall events can be recognised by a simultaneous increase in albedo at both locations. In all years, the snow disappears earlier in summer at the AWS site on Midtdalsbreen than on Storbreen. The time difference in ice reappearance at the two locations varies between 11 days (2003) and 35 days (2002) and is weakly related to the maximum snow depth and the difference in total snow accumulation at the two locations. In the winter 2001-2002, Midtdalsbreen received considerably less snow than Storbreen, leading to the largest difference in ice reappearance dates. Ice albedo on Midtdalsbreen remained rather high during the summer of 2002 for unknown reasons. In general, ice albedo has a value around 0.3 at both locations, but can get as low as 0.22 .

Annual mean reflected shortwave radiation is slightly larger on Midtdalsbreen $\left(+6 \mathrm{~W} \mathrm{~m}^{-2}\right)$, due to more incoming solar radiation (Table 2). For the period with surface melt, the difference between the two glaciers becomes very small $\left(+1 \mathrm{~W} \mathrm{~m}^{-2}\right)$, mainly a result of the earlier disappearance of the snowpack on Midtdalsbreen. As the difference between absolute $S_{\text {out }}$ at the two locations is small, $S_{\text {net }}$ is larger on Midtdalsbreen (Fig. 9).

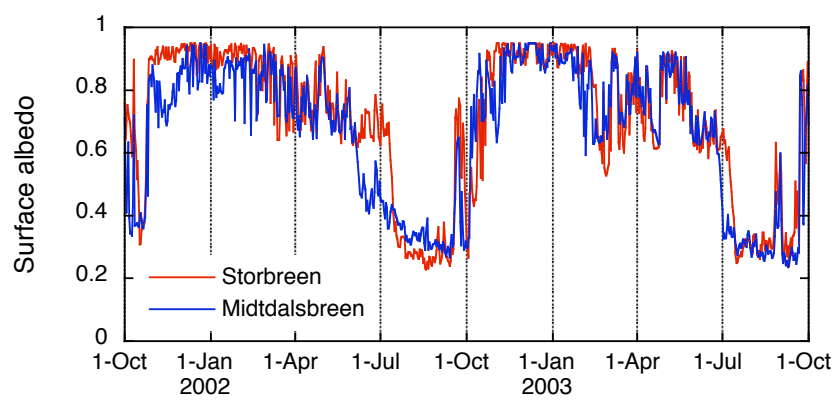

Fig. 8. Daily mean surface albedo on Storbreen and Midtdalsbreen from October 2001 to October 2003.

\subsection{Longwave radiation}

Annual mean incoming longwave radiation is comparable at the two AWS locations (Table 2). However, in summer monthly averaged $L_{\text {in }}$ is 4 to $6 \mathrm{~W} \mathrm{~m}^{-2}$ larger on Storbreen, while during the winter season $L_{\text {in }}$ is often larger on Midtdalsbreen. In summer, thicker clouds on Storbreen result in larger $L_{\text {in }}$ than on Midtdalsbreen (Fig. $7 \mathrm{~b}$ ), as was already discussed in Sect. 4.3. The larger $L_{\text {in }}$ for Midtdalsbreen during the winter months is a result of occasional multi-day periods with substantially more humid and cloudier weather than on Storbreen.

Outgoing longwave radiation is similar at the two locations, values are slightly higher on Midtdalsbreen, as surface temperatures are higher due to more positive energy fluxes towards the surface. During the melt season, the surface is almost continuously at the melting point and $L_{\text {out }}$ is approximately equal at the AWS sites. The combination of higher $L_{\text {in }}$ and lower $L_{\text {out }}$ on Storbreen compared to Midtdalsbreen, results in less negative $L_{\text {net }}$ on Storbreen (Fig. 9). 

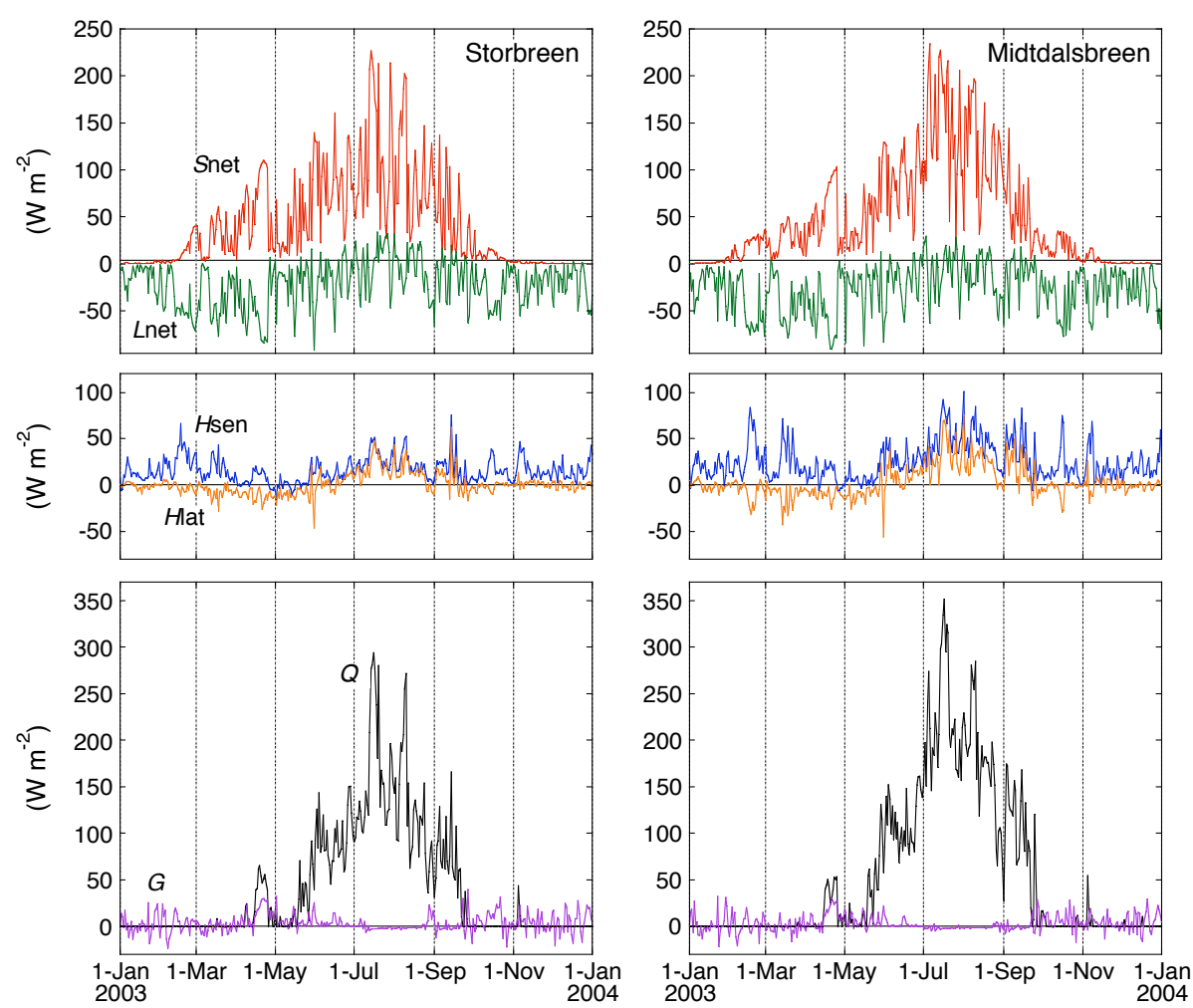

Fig. 9. Daily mean surface energy fluxes on Storbreen and Midtdalsbreen in 2003.
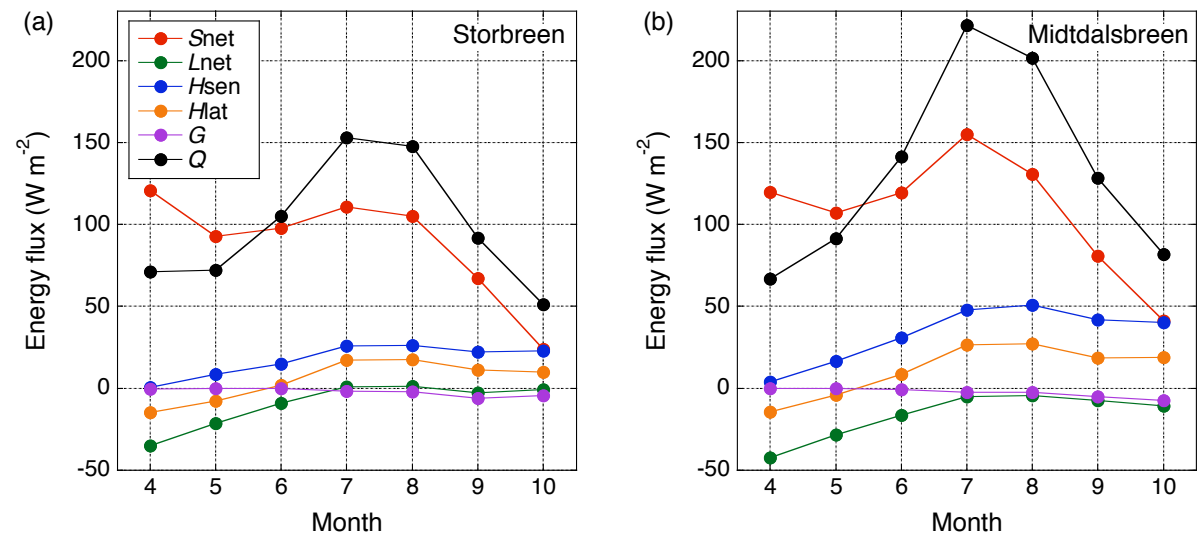

Fig. 10. Monthly mean values of the surface energy fluxes during melt for (a) Storbreen and (b) Midtdalsbreen. 

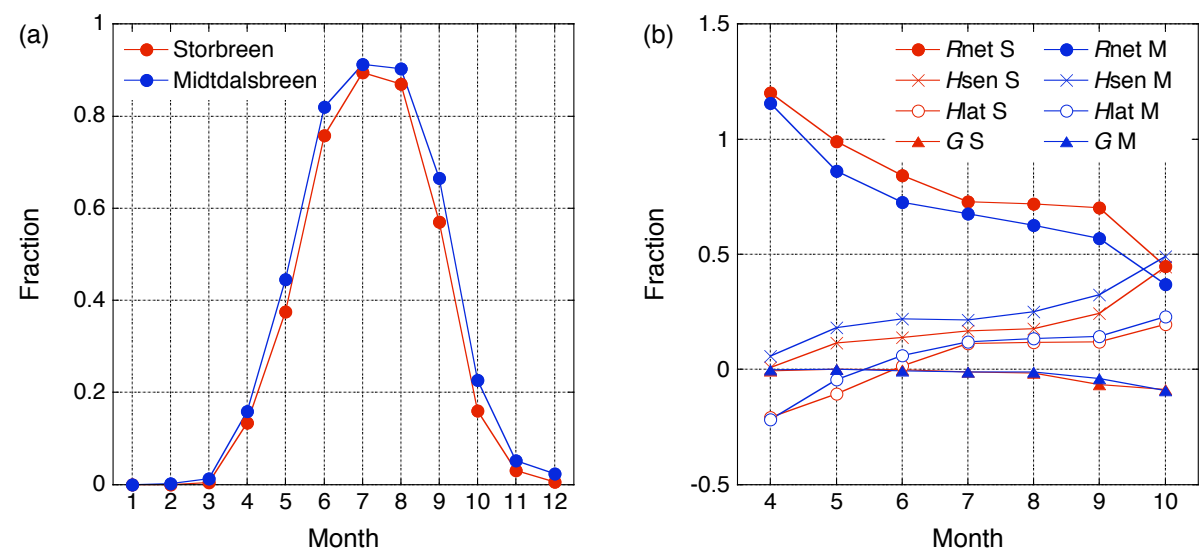

Fig. 11. Monthly values of (a) the fraction of time with melt and (b) the contribution of the energy fluxes to surface melt on Storbreen (S) and Midtdalsbreen (M).

\subsection{Turbulent fluxes}

On both glaciers, the daily mean sensible heat flux is almost permanently positive (Fig. 9), as the daily average surface temperature is seldom higher than the air temperature. The sensible heat flux is generally larger on Midtdalsbreen, especially in summer, which is a result of the higher air temperatures and higher wind speeds.

The latent heat flux is mainly negative and partly balances the sensible heat flux (Fig. 9). Again, the absolute values of $H_{\text {lat }}$ are generally larger on Midtdalsbreen, because of the more humid and windier conditions. During summer, both $H_{\text {sen }}$ and $H_{\text {lat }}$ are positive and contribute substantially to the energy available for melting (Fig. 10).

\subsection{Subsurface heat flux}

The subsurface heat flux warms or cools the surface depending on the sign of the sum of the atmospheric energy fluxes. Daily mean values only occasionally exceed $20 \mathrm{~W} \mathrm{~m}^{-2}$ and are small compared to the other energy fluxes (Fig. 9). The subsurface heat fluxes are similar in magnitude and interdaily fluctuations at the two AWS sites. In the early melt season, when the surface consists of snow, $G$ is generally zero or positive as the entire snowpack is at the melting point temperature. As soon as the snow has disappeared, $G$ becomes slightly negative. The glacier ice is still cold because it was isolated by the snowpack during spring; all through the melt season a small amount of energy is used to warm the ice. The model does not include penetration of shortwave radiation, but in reality the near-surface ice is likely heated by penetrating shortwave radiation during the day. This process creates an isothermal layer causing $G$ to vanish.

\subsection{Melting energy}

The energy available for melting is, on average, a factor 1.3 larger on Midtdalsbreen. Net radiation $R_{\text {net }}$, the sum of the shortwave and longwave radiative fluxes, is 1.2 times larger than on Storbreen, the turbulent fluxes are almost twice as large (factor 1.9). On both Storbreen and Midtdalsbreen, the surface is melting almost continuously during July and August (Fig. 11a). The main melt season is between May and October, when $S_{\text {net }}$ dominates over $L_{\text {net }}$ and the sum of $H_{\text {sen }}$ and $H_{\text {lat }}$ is positive (Fig. 9). In the winter months, melt occurs sporadically. During the five years considered in this study, the glacier surface at the AWS site on Storbreen was melting $32 \%$ of the time, on Midtdalsbreen this percentage is $35 \%$. The relative contribution of the energy fluxes to the surface melt for the months between April to October is illustrated in Fig. 11b. Note that only periods with melt are included in this calculation. In early spring, the contribution of $R_{\text {net }}$ to surface melt is larger than unity, to balance the negative $H_{\text {lat }}$. In fact, $S_{\text {net }}$ needs to compensate $H_{\text {lat }}$ and $L_{\text {net }}$ which are both negative (Fig. 10), implying that large $S_{\text {in }}$ is required for melt in spring. The relative importance of $R_{\text {net }}$ decreases during the melt season, when topof-the-atmosphere solar irradiance becomes smaller, cloudiness increases and the turbulent fluxes increase due to higher wind speeds. In October, $S_{\text {net }}$ and $H_{\text {sen }}$ contribute equally to the melt energy and the turbulent fluxes together dominate the surface energy balance (Figs. 10 and 11b). The largest melt fluxes occur on Midtdalsbreen in July, on Storbreen the amount of melt in July is significantly lower and comparable to melt in August. The main cause for this difference is the earlier disappearance of the snowpack on Midtdalsbreen, which happens in June or early July. The lower ice albedo enhances the amount of energy supplied by $S_{\text {net }}$. Net radiation dominates the surface energy balance at both AWS sites, but its relative contribution is larger on Storbreen. Over the entire period with melt its fraction of the total melt energy is 0.76 on Storbreen and 0.66 on Midtdalsbreen.

\subsection{Accumulation and ablation}

Snow accumulation is highly variable from year to year, but generally similar in timing and magnitude at the two 


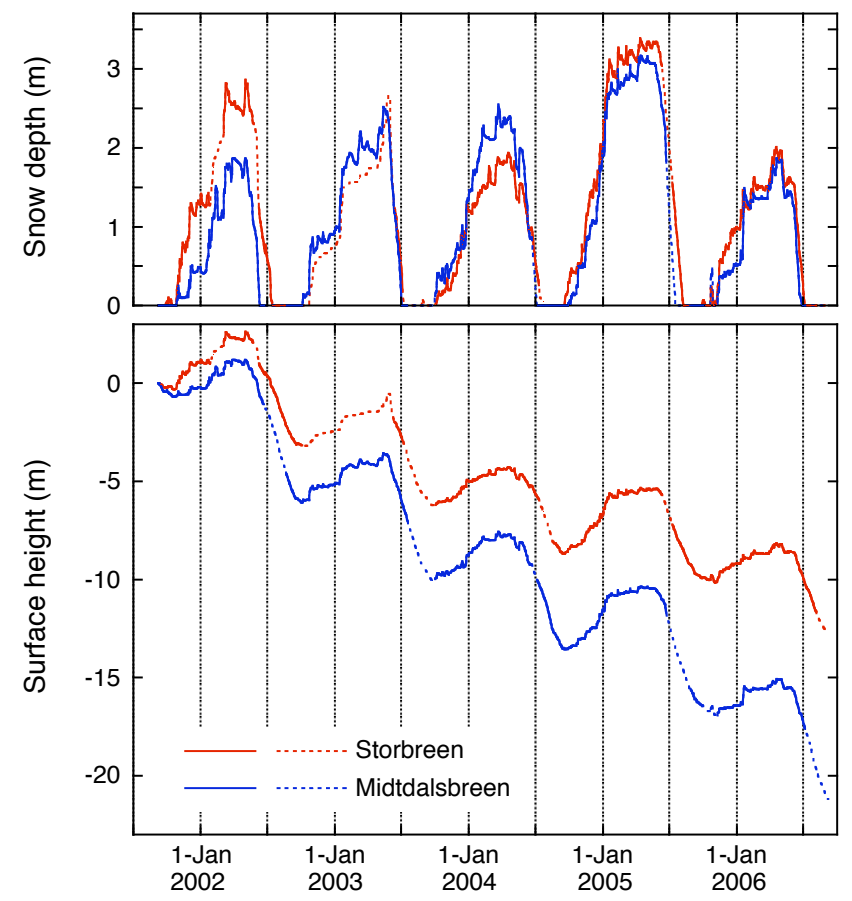

Fig. 12. Daily values of (a) snow depth and (b) cumulative surface height at the AWS sites on Storbreen and Midtdalsbreen for the entire period. Direct measurements from the sonic ranger are shown as solid lines, accumulation estimated from precipitation data and ablation computed with the energy balance model are drawn with dashed lines.

AWS sites (Fig. 12a). The similarity between the snow depth records indicates that the two glaciers are situated in a similar precipitation regime, even though Fig. 1 suggests a slightly more maritime climate on Midtdalsbreen. The largest differences between the two records occur when a heavy snowfall event takes place at only one of the two locations. To determine whether these occasional events are related to local or large-scale wind directions, we selected the periods with large differences in snow accumulation. For these periods, we examined both the wind direction measured at the AWS sites as well as the wind direction at the $850 \mathrm{hPa}$ level from (re-)analyses by the European Centre for Medium-Range Weather Forecasts (ECMWF), but no relation was found. On several days with more snowfall on Storbreen, wind speeds were higher than $10 \mathrm{~m} \mathrm{~s}^{-1}$ on Midtdalsbreen, pointing towards fresh snow removal by snowdrift and sublimation. However, during other windy periods on Midtdalsbreen snow accumulation was similar or higher than on Storbreen, hence no common cause for the snowfall differences could be established.

The larger energy fluxes on Midtdalsbreen lead to a higher ablation rate than on Storbreen. The snowpack on Midtdalsbreen melts away more quickly in spring, resulting in a longer period with ice at the surface. For the five years considered in this study, the surface became snow-free be- tween 10 June (in 2002) and 17 July (in 2005) on Midtdalsbreen, while on Storbreen the ice reappeared between 4 July (in 2006) and 12 August (in 2005). Over the entire period, the cumulative ice melt is 1.7 times larger on Midtdalsbreen (Fig. 12b). To quantify the effect of the earlier disappearance of the snowpack on Midtdalsbreen on the total ice melt, we compared the amount of ice melted in the periods with a snow-free surface at both locations. For these periods, cumulative ice melt on Midtdalsbreen is 30\% larger than on Storbreen, entirely the result of the larger energy fluxes on Midtdalsbreen. Hence the effect of the earlier reappearance of the ice surface on Midtdalsbreen in the five summers considered, is as large as $40 \%$.

\section{Discussion}

\subsection{Uncertainties in measurements and calculations}

Meteorological quantities measured on Storbreen and Midtdalsbreen were found to be generally highly correlated, while absolute differences can be considerable. The identical design of the AWSs minimizes uncertainties due to different instruments, sample intervals or measurement heights. Besides uncertainties due to measurement errors, the results from the energy balance model depend on the values chosen for the model parameters. By applying the same model to both data sets, we exclude uncertainties introduced by different model equations or computation methods. We estimated the accuracy of the measured and modelled variables, considering random and systematic measurement errors as well as uncertainties arising from processing steps and the model design (Table 2). In this section, we discuss the largest error sources and implications for the energy balance calculations.

Incoming solar radiation has the largest uncertainty of the measured variables. The instrument accuracy given by the manufacturers is $\pm 10 \%$ for daily totals (Andreassen et al., 2008), suggesting large potential errors in daily values when solar irradiance is large. However, these random errors are considerably reduced when averaging over longer periods. Tilting of the mast is a possible source for systematic errors. We were able to reduce the systematic error in $S_{\text {in }}$ with a tilt correction, but because only the approximate tilt angle is known, large uncertainties remain. Daily mean values for the tilt corrections applied to the solar radiation data from Midtdalsbreen rarely exceed $\pm 10 \mathrm{~W} \mathrm{~m}^{-2}$. We investigated the effect of the tilt correction on the energy balance by recalculating the $S_{\text {in }}$ values reported in Table 2 for Midtdalsbreen with uncorrected solar radiation measurements. The resulting annual and melt period mean values are 1 and $8 \mathrm{~W} \mathrm{~m}^{-2}$ higher, respectively; the contribution of net radiation to melt slightly increases from $66 \%$ to $68 \%$. We assume that the applied tilt correction has reduced the errors in $S_{\text {in }}$, hence the remaining uncertainty is expected to be smaller than the values presented above. 
The effective cloud optical depth calculated from the AWS measurements also has a large uncertainty (Table 2). The parameterization requires solar incoming radiation measurements for an unshaded site and can therefore only be determined during daytime when the solar zenith angle is large enough. An exponential relation with daily mean cloud fraction values was used to obtain the effective cloud optical depth for all days (Sect. 3.2), including winter days with allday shading of the AWS site. Although the fitted function describes the relation between cloud fraction and cloud optical depth well, large uncertainties are associated with the computed values for individual days.

The largest model uncertainties result from the calculation of the turbulent fluxes, as the available data only provide estimates for the stability correction and the surface roughness length, due to the limited number of usable data and the highly variable nature of the surface and the boundarylayer. Giesen et al. (2008) investigated the sensitivity of the turbulent fluxes and modelled melt to changes in the roughness length for momentum and the stability correction. When $z_{0 v}$ on Midtdalsbreen is increased to $5 \mathrm{~mm}$, the sum of the mean turbulent fluxes during melt becomes $9 \mathrm{~W} \mathrm{~m}^{-2}$ higher, while the contribution of the turbulent fluxes to melt increases by $4 \%$. Omitting the stability correction has a similar effect on the results; applying the full stability correction reduces the absolute and relative contributions to melt by the turbulent fluxes by a comparable magnitude. As the values for $z_{0 v}$ and the stability correction used in this study have been derived from local observations, we expect that these sensitivity tests give the upper limit of uncertainties associated with the turbulent fluxes on Midtdalsbreen. Uncertainties in the turbulent fluxes will have a smaller effect on the energy balance at Storbreen, where the turbulent fluxes are less important than on Midtdalsbreen.

Although the uncertainties in the results introduced by measurement errors and model uncertainties are considerable (Table 2), they are mostly smaller than the observed differences in meteorological quantities between the two locations. Hence, it is unlikely that these differences result from measurement or model uncertainties.

\subsection{Comparison to other glaciers}

To compare the surface energy fluxes on Storbreen and Midtdalsbreen with values on other glaciers, we selected a number of energy balance studies conducted on glaciers at comparable latitudes, between $50^{\circ}$ and $70^{\circ}$ on both hemispheres. Table 3 lists the absolute values for the energy fluxes found in these studies and their contribution to the energy balance. The reported values are mostly averages over the measurement period and not specifically for a melting surface. However, most studies are conducted during the main melt season and the surface is often assumed or found to be melting continuously. The mean air temperature $T_{\mathrm{a}}$ and wind speed $v$ at the study sites are also listed in Table 3, when reported. Hu- midity is not included because it is less often reported and cannot be compared directly as some studies report relative and others absolute humidity values.

The mean absolute and relative values for the energy fluxes on Storbreen found in this study are higher than those reported for Storbreen for the summer of 1955 (Liestøl, 1967), but the numbers reported for 1955 are within the range of the annual values reported for the period 2001-2006 (Andreassen et al., 2008). Energy fluxes at the AWS site on Storbreen compare both in absolute and relative numbers to McCall Glacier (Klok et al., 2005). The total melt energy is also comparable to values reported for Storglaciären (Hock and Holmgren, 1996), Nordbogletscher (Braithwaite and Olesen, 1990) and Omnsbreen (Messel, 1971), but at those locations turbulent fluxes are more important. In fact, Storbreen has the highest contribution by net radiation of all the selected studies. A probable explanation is that many of the glaciers in this latitude range are situated in more maritime climates than Storbreen, but the surface albedo on Storbreen may also be lower. In relative numbers, the values found for Midtdalsbreen in this study compare well to those reported for Storglaciären, Qamanârssûp sermia (Braithwaite and Olesen, 1990), Ecology Glacier (Bintanja, 1995) and the measurements at $2300 \mathrm{~m}$ a.s.l. on Peyto Glacier (Munro, 1990), which were obtained above an ice surface. The absolute values for net radiation and total melt energy on Midtdalsbreen are similar to those measured on Qamanârssûp sermia and Peyto Glacier as well, although the values for the separate turbulent fluxes are different. The melting energy on Midtdalsbreen is considerably larger than on Omnsbreen, a small glacier located approximately $11 \mathrm{~km}$ north of Midtdalsbreen. The values for the turbulent fluxes measured on the two glaciers are comparable, but net radiation is much smaller on Omnsbreen. During the investigation period in 1968, Omnsbreen remained snow-covered, in 1969 the ice was not exposed before 21 July (Messel, 1971). The higher surface albedo on Omnsbreen resulted in smaller net radiation than during melt periods on Midtdalsbreen.

The magnitude of the energy fluxes on Storbreen and Midtdalsbreen lies in between numbers reported for other glaciers at comparable latitudes. However, no simple dependencies of the absolute or relative energy fluxes on latitude, altitude, air temperature or wind speed could be found for the studies listed in Table 3. There are several reasons why a thorough comparison between these studies cannot be made. First, the measurements were obtained in different years and interannual variability can be large. Second, at the latitudes considered here, the absolute values and relative contributions of the energy fluxes change significantly during the melt season (Figs. 9 and 11b), hence the period of measurement largely influences the results. Furthermore, measurements are made over different surface types (snow and/or ice) and the range in altitudes is large, influencing the absolute values of the energy fluxes and their relative contribution to the energy balance. Moreover, in the selected studies various 
Table 3. Mean values of the energy fluxes $\left(\mathrm{W} \mathrm{m}^{-2}\right)$ and relative contribution to the surface energy balance (\%, boldface numbers) from several energy balance studies. Values are rounded to the nearest integer. $H_{\mathrm{r}}$ is heat supplied by rain. The total melt energy $Q$ is the sum of the individual energy fluxes, not measured ablation as these are not always equal. When reported, the surface type (snow/firn/ice), altitude (m a.s.l.), mean air temperature $T_{\mathrm{a}}\left({ }^{\circ} \mathrm{C}\right)$ and wind speed $v\left(\mathrm{~m} \mathrm{~s}^{-1}\right)$ at the study site are also listed.

\begin{tabular}{|c|c|c|c|c|c|c|c|c|c|c|}
\hline $\begin{array}{l}\text { Location } \\
\text { Reference }\end{array}$ & Latitude & Period & $\begin{array}{l}\text { Surface } \\
\text { Altitude }\end{array}$ & $\begin{array}{c}T_{\mathrm{a}} \\
v\end{array}$ & $R_{\text {net }}$ & $H_{\text {sen }}$ & $H_{\text {lat }}$ & $H_{\mathrm{r}}$ & $G$ & $Q$ \\
\hline $\begin{array}{l}\text { McCall Glacier, Alaska } \\
\quad \text { (Klok et al., 2005) }\end{array}$ & $69^{\circ} \mathrm{N}$ & $\begin{array}{l}15 \text { Jun-20 Aug } \\
2004\end{array}$ & $\begin{array}{c}\text { snow/ice } \\
1715\end{array}$ & $\begin{array}{l}5.3 \\
3.1\end{array}$ & $\begin{array}{l}93 \\
74\end{array}$ & $\begin{array}{l}31 \\
25\end{array}$ & $\begin{array}{l}6 \\
5\end{array}$ & - & $\begin{array}{l}-5 \\
-4\end{array}$ & 125 \\
\hline $\begin{array}{l}\text { Storglaciären, Sweden } \\
\quad \text { (Hock and Holmgren, 1996) }\end{array}$ & $68^{\circ} \mathrm{N}$ & $\begin{array}{c}19 \text { Jul-27 Aug } \\
1994\end{array}$ & $\begin{array}{c}\text { snow/ice } \\
1370\end{array}$ & $\begin{array}{l}5.4 \\
2.5\end{array}$ & $\begin{array}{l}73 \\
66\end{array}$ & $\begin{array}{l}33 \\
30\end{array}$ & $\begin{array}{l}5 \\
5\end{array}$ & - & $\begin{array}{l}-3 \\
-3\end{array}$ & 110 \\
\hline $\begin{array}{l}\text { Qamanârssûp sermia, Greenland } \\
\text { (Braithwaite and Olesen, 1990) }\end{array}$ & $64^{\circ} \mathrm{N}$ & $\begin{array}{l}1 \text { Jun-31 Aug } \\
\text { 1980-1986 }\end{array}$ & $\begin{array}{l}\text { ice } \\
790\end{array}$ & $\begin{array}{l}- \\
-\end{array}$ & $\begin{array}{r}103 \\
64\end{array}$ & $\begin{array}{l}62 \\
39\end{array}$ & $\begin{array}{l}-6 \\
-4\end{array}$ & - & - & 161 \\
\hline $\begin{array}{l}\text { West Gulkana Glacier, Alaska } \\
\text { (Brazel et al., 1992) }\end{array}$ & $63^{\circ} \mathrm{N}$ & $\begin{array}{c}21 \text { Jun-19 Jul } \\
1986\end{array}$ & $\begin{array}{c}\text { snow/ice } \\
1520\end{array}$ & $\begin{array}{l}- \\
-\end{array}$ & $\begin{array}{l}79 \\
57\end{array}$ & $\begin{array}{l}49 \\
35\end{array}$ & $\begin{array}{r}11 \\
8\end{array}$ & $\begin{array}{l}1 \\
\mathbf{0}\end{array}$ & - & 139 \\
\hline $\begin{array}{l}\text { Ecology Glacier, King George Island } \\
\quad \text { (Bintanja, 1995) }\end{array}$ & $62^{\circ} \mathrm{S}$ & $\begin{array}{l}17 \text { Dec-16 Jan } \\
\text { 1990-1991 }\end{array}$ & $\begin{array}{c}\text { snow/ice } \\
100\end{array}$ & $\begin{array}{l}1.9 \\
5.7\end{array}$ & $\begin{array}{l}61 \\
64\end{array}$ & $\begin{array}{l}27 \\
29\end{array}$ & $\begin{array}{l}7 \\
7\end{array}$ & - & - & 96 \\
\hline $\begin{array}{l}\text { Storbreen, Norway } \\
\quad \text { (Liestøl, 1967) }\end{array}$ & $62^{\circ} \mathrm{N}$ & $\begin{array}{c}6 \text { Jul-8 Sep } \\
1955\end{array}$ & $\begin{array}{l}\text { snow/ice } \\
1600\end{array}$ & $\begin{array}{l}- \\
-\end{array}$ & $\begin{array}{l}73 \\
56\end{array}$ & $\begin{array}{l}40 \\
\mathbf{3 1}\end{array}$ & $\begin{array}{l}17 \\
\mathbf{1 3}\end{array}$ & - & - & 130 \\
\hline $\begin{array}{l}\text { Storbreen, Norway } \\
\text { (this study) }\end{array}$ & $62^{\circ} \mathrm{N}$ & $\begin{array}{l}7 \text { Sep-6 Sep } \\
\text { 2001-2006 }\end{array}$ & $\begin{array}{l}\text { snow/ice } \\
1570\end{array}$ & $\begin{array}{l}4.9 \\
3.3\end{array}$ & $\begin{array}{l}89 \\
76\end{array}$ & $\begin{array}{l}20 \\
17\end{array}$ & $\begin{array}{l}9 \\
8\end{array}$ & - & $\begin{array}{l}-2 \\
-2\end{array}$ & 117 \\
\hline $\begin{array}{l}\text { Nordbogletscher, Greenland } \\
\quad \text { (Braithwaite and Olesen, 1990) }\end{array}$ & $61^{\circ} \mathrm{N}$ & $\begin{array}{l}\text { 1 Jun-31 Aug } \\
\text { 1979-1983 }\end{array}$ & $\begin{array}{l}\text { ice } \\
880\end{array}$ & $\begin{array}{l}- \\
-\end{array}$ & $\begin{array}{l}79 \\
71\end{array}$ & $\begin{array}{l}32 \\
29\end{array}$ & $\begin{array}{l}2 \\
2\end{array}$ & - & - & 111 \\
\hline $\begin{array}{l}\text { Worthington Glacier, Alaska } \\
\text { (Streten and Wendler, 1968) }\end{array}$ & $61^{\circ} \mathrm{N}$ & $\begin{array}{c}\text { 16 Jul-1 Aug } \\
1967\end{array}$ & $\begin{array}{l}\text { ice } \\
\pm 850\end{array}$ & $\begin{array}{l}9.6 \\
2.1\end{array}$ & $\begin{array}{r}127 \\
\mathbf{5 1}\end{array}$ & $\begin{array}{l}68 \\
29\end{array}$ & $\begin{array}{l}47 \\
20\end{array}$ & - & - & 242 \\
\hline $\begin{array}{l}\text { Omnsbreen, Norway } \\
\text { (Messel, 1971) }\end{array}$ & $60^{\circ} \mathrm{N}$ & $\begin{array}{l}3 \text { Jun-8 Sep } \\
1968-1969\end{array}$ & $\begin{array}{l}\text { snow/ice } \\
1540\end{array}$ & $\begin{array}{l}- \\
-\end{array}$ & $\begin{array}{l}57 \\
\mathbf{5 2}\end{array}$ & $\begin{array}{l}35 \\
32\end{array}$ & $\begin{array}{l}16 \\
15\end{array}$ & - & - & 108 \\
\hline $\begin{array}{l}\text { Midtdalsbreen, Norway } \\
\text { (this study) }\end{array}$ & $60^{\circ} \mathrm{N}$ & $\begin{array}{l}7 \text { Sep-6 Sep } \\
\text { 2001-2006 }\end{array}$ & $\begin{array}{c}\text { snow/ice } \\
1450\end{array}$ & $\begin{array}{l}5.3 \\
6.0\end{array}$ & $\begin{array}{r}104 \\
66\end{array}$ & $\begin{array}{l}39 \\
25\end{array}$ & $\begin{array}{l}16 \\
\mathbf{1 1}\end{array}$ & - & $\begin{array}{l}-2 \\
-2\end{array}$ & 157 \\
\hline $\begin{array}{l}\text { Lemon Creek Glacier, Alaska } \\
\text { (Wendler and Streten, 1969) }\end{array}$ & $58^{\circ} \mathrm{N}$ & $\begin{array}{c}5 \text { Aug-20 Aug } \\
1968\end{array}$ & $\begin{array}{c}\text { firn } \\
1200\end{array}$ & $\begin{array}{l}7.6 \\
1.5\end{array}$ & $\begin{array}{l}41 \\
48\end{array}$ & $\begin{array}{l}36 \\
43\end{array}$ & $\begin{array}{l}8 \\
9\end{array}$ & - & - & 84 \\
\hline $\begin{array}{l}\text { Koryto Glacier, Russia } \\
\text { (Konya et al., 2004) }\end{array}$ & $55^{\circ} \mathrm{N}$ & $\begin{array}{l}7 \text { Aug-12 Sep } \\
2000\end{array}$ & $\begin{array}{c}\text { snow } \\
810\end{array}$ & $\begin{array}{l}7.6 \\
2.4\end{array}$ & $\begin{array}{l}43 \\
\mathbf{3 3}\end{array}$ & $\begin{array}{l}59 \\
44\end{array}$ & $\begin{array}{l}31 \\
\mathbf{2 3}\end{array}$ & - & - & 133 \\
\hline $\begin{array}{l}\text { Hodges Glacier, South Georgia } \\
\text { (Hogg et al., 1982) }\end{array}$ & $54^{\circ} \mathrm{S}$ & $\begin{array}{l}1 \text { Nov-4 Apr } \\
1973-1974\end{array}$ & $\begin{array}{l}\text { snow/ice } \\
375\end{array}$ & - & $\begin{array}{l}47 \\
55\end{array}$ & $\begin{array}{l}41 \\
48\end{array}$ & $\begin{array}{r}-2 \\
-3\end{array}$ & - & - & 86 \\
\hline $\begin{array}{l}\text { Glaciar Lengua, Chile } \\
\text { (Schneider et al., 2007) }\end{array}$ & $53^{\circ} \mathrm{S}$ & $\begin{array}{l}28 \mathrm{Feb}-12 \mathrm{Apr} \\
2000\end{array}$ & $\begin{array}{l}\text { ice } \\
450\end{array}$ & $\begin{array}{l}5.9 \\
4.1\end{array}$ & $\begin{array}{l}57 \\
35\end{array}$ & $\begin{array}{l}86 \\
54\end{array}$ & $\begin{array}{r}12 \\
7\end{array}$ & $\begin{array}{l}7 \\
4\end{array}$ & - & 162 \\
\hline $\begin{array}{l}\text { Peyto Glacier, Canada } \\
\text { (Munro, 1990) }\end{array}$ & $52^{\circ} \mathrm{N}$ & $\begin{array}{c}17 \text { Jun-6 Jul } \\
1988 \\
21 \text { Jun-5 Jul } \\
1988\end{array}$ & $\begin{array}{c}\text { ice } \\
2300 \\
\text { snow } \\
2500\end{array}$ & $\begin{array}{l}- \\
- \\
- \\
-\end{array}$ & $\begin{array}{r}108 \\
\mathbf{6 5} \\
39 \\
\mathbf{5 1}\end{array}$ & $\begin{array}{l}57 \\
\mathbf{3 4} \\
32 \\
\mathbf{4 2}\end{array}$ & $\begin{array}{l}2 \\
1 \\
5 \\
7\end{array}$ & - & - & 166 \\
\hline $\begin{array}{l}\text { Tyndall Glacier, Chile } \\
\text { (Takeuchi et al., 1995a,b) }\end{array}$ & $51^{\circ} \mathrm{S}$ & $\begin{array}{l}9 \text { Dec-17 Dec } \\
1993\end{array}$ & $\begin{array}{l}\text { ice } \\
700\end{array}$ & $\begin{array}{l}5.1 \\
6.6\end{array}$ & $\begin{array}{r}137 \\
\mathbf{5 1}\end{array}$ & $\begin{array}{r}111 \\
42\end{array}$ & $\begin{array}{r}19 \\
7\end{array}$ & - & - & 266 \\
\hline $\begin{array}{l}\text { Moreno Glacier, Chile } \\
\text { (Takeuchi et al., 1995a,b) }\end{array}$ & $50^{\circ} \mathrm{S}$ & $\begin{array}{c}12 \text { Nov-27 Nov } \\
1993\end{array}$ & $\begin{array}{l}\text { ice } \\
330\end{array}$ & $\begin{array}{l}7.9 \\
4.9\end{array}$ & $\begin{array}{r}139 \\
\mathbf{5 4}\end{array}$ & $\begin{array}{r}126 \\
49\end{array}$ & $\begin{array}{l}-9 \\
-4\end{array}$ & - & - & 256 \\
\hline
\end{tabular}

methods are applied to calculate the turbulent fluxes and the contribution of the fluxes to surface melt, which should as well be considered when comparing results. The values reported in Table 3 for Storbreen and Midtdalsbreen are averages over half-hourly periods with surface melt, as given by the energy balance model. Changing to hourly instead of half-hourly intervals reduced the reported fluxes by 1 to $2 \%$, whereas the relative contributions to melt did not change notably. Although the surface on Storbreen and Midtdals- breen was always melting during the day in July and August, the surface temperature dropped below the melting point on clear-sky nights. If we had included the periods without melt in our calculation, the average values for net radiation in July and August had been 13\% (Midtdalsbreen) and 18\% (Storbreen) lower. The turbulent fluxes and the subsurface heat flux at the two AWS locations were found to be less sensitive to including periods without melt, as they have a smaller daily cycle. The contribution to melt by the different fluxes 
Table 4. Mean values and linear correlations of daily mean values of meteorological quantities for Storbreen (S), Sognefjellhytta (So), Midtdalsbreen (M) and Finsevatn (F) over the period 7 September 2001-6 September 2006, for all days with data available for all stations.

\begin{tabular}{|c|c|c|c|c|c|c|c|c|c|c|c|}
\hline \multirow[t]{2}{*}{ Variable } & \multirow{2}{*}{$\begin{array}{l}\text { Number } \\
\text { of days }\end{array}$} & \multirow{2}{*}{$\begin{array}{r}\text { Coverage } \\
(\%)\end{array}$} & \multicolumn{4}{|c|}{ Mean } & \multicolumn{5}{|c|}{ Correlation } \\
\hline & & & $S$ & M & So & $\mathrm{F}$ & S-So & $\mathrm{S}-\mathrm{F}$ & M-So & $\mathrm{M}-\mathrm{F}$ & So-F \\
\hline Air temperature $\left({ }^{\circ} \mathrm{C}\right)$ & 1518 & 83 & -2.4 & -1.7 & -2.1 & -1.4 & 0.98 & 0.92 & 0.98 & 0.94 & 0.97 \\
\hline Relative humidity (\%) & 927 & 51 & 76.4 & 80.6 & 83.6 & 88.3 & 0.80 & 0.52 & 0.78 & 0.66 & 0.76 \\
\hline Specific humidity $\left(\mathrm{g} \mathrm{kg}^{-1}\right)$ & 805 & 44 & 3.0 & 3.2 & 3.3 & 3.6 & 0.99 & 0.98 & 0.98 & 0.99 & 0.99 \\
\hline Wind speed $\left(\mathrm{m} \mathrm{s}^{-1}\right)$ & 1549 & 85 & 3.8 & 6.6 & 3.9 & 5.2 & 0.70 & 0.71 & 0.72 & 0.90 & 0.75 \\
\hline Air pressure $(\mathrm{hPa})$ & 1305 & 71 & 834.0 & 848.5 & 850.5 & 872.9 & 1.00 & 0.99 & 1.00 & 1.00 & 1.00 \\
\hline
\end{tabular}

changed by only 1-3\% when periods without melt in July and August were included. We conclude that a thorough comparison between energy fluxes at two different locations can only be made when the period of measurement and the methods applied to determine the turbulent fluxes and the contribution to melt are identical, as they are in the present study.

\subsection{Comparison to nearby weather stations}

As glacio-meteorological records are only available for a limited number of glaciers, mass and energy balance models are mostly driven by meteorological data measured at a distance from the glacier of interest. Although air temperature and air pressure are generally correlated over relatively large distances, variables like wind speed and cloudiness depend on small-scale topography and other local conditions. In this section we compare the records from Storbreen and Midtdalsbreen with measurements from two NMI weather stations located close to the respective glaciers. Sognefjellhytta (1413 m a.s.1.) is situated $8 \mathrm{~km}$ south-west from Storbreen, Finsevatn (1210 m a.s.l.) is located $4 \mathrm{~km}$ north-east from the AWS on Midtdalsbreen. Both stations are automatic weather stations with hourly measurements of air temperature, relative humidity, air pressure, wind speed and wind direction. Precipitation is measured at Finsevatn, but is excluded from the comparison as these measurements are very uncertain at automatic weather stations and only snow accumulation is recorded at the AWSs on Storbreen and Midtdalsbreen. Relative humidity measurements were corrected for temperatures below $0^{\circ} \mathrm{C}$ (Sect. 3.1). Specific humidity has been calculated from air temperature, relative humidity and air pressure when these three variables were available. Mean values and linear correlations $(r)$ have been computed for all days with measurements from all four stations (Table 4) and are not annual mean values. The relative humidity record from Finsevatn contains large data gaps, hence the number of days included for relative and specific humidity is much smaller than for the other variables.

Daily mean air temperatures at Storbreen, Midtdalsbreen and Sognefjellhytta are highly correlated, while correlations with air temperatures at Finsevatn are considerably lower. On clear-sky days, the diurnal temperature cycle is much stronger at Sognefjellhytta and Finsevatn than at the glacier sites (Fig. 13). On such days, low wind speeds are recorded outside the glaciers, promoting heating of the near-surface air during the day and strong cooling at night. On the sloping glacier surface, wind speeds are higher and the air is better mixed. Since especially the clear-sky nights are colder outside the glaciers, mean air temperatures for Sognefjellhytta and Finsevatn are lower than expected from an extrapolation of the mean air temperatures at the glacier sites.

The highest wind speeds are measured on Midtdalsbreen and are well correlated with wind speeds at Finsevatn, while the correlation of wind speeds at other locations is significantly lower. Wind directions at Sognefjellhytta and Finsevatn have two very pronounced directions (Fig. 14), on Midtdalsbreen and Storbreen wind directions are more variable. Although the dominant wind directions at Sognefjellhytta and Finsevatn differ, westerly or south-easterly winds occur at the same time, hence the measured wind direction is likely a large-scale wind direction modified by local topography. These large-scale winds are often recorded on Midtdalsbreen, while on Storbreen down-glacier winds are dominant and large-scale wind directions only occur occasionally. The comparison with Sognefjellhytta and Finsevatn supports the supposition (Sect. 4.2) that wind characteristics at Midtdalsbreen are generally determined by the large-scale circulation and that wind speeds on Storbreen are often of a local nature.

To investigate how a change in meteorological input data affects the calculated energy balance for Storbreen and Midtdalsbreen, we performed additional model runs with air temperature, relative humidity or wind speed taken from a different location. The only melt season with these three variables available for all four AWSs, is the summer of 2006. To capture the entire melt season, the model was run from 1 March to 8 September 2006, the end of the records from Storbreen and Midtdalsbreen. We applied a lapse rate of $6.0^{\circ} \mathrm{C} \mathrm{km}^{-1}$ to extrapolate air temperatures to the glacier AWS altitudes. We estimated the change in incoming longwave radiation from the new air temperature and cloud cover by inverting the method by Van den Broeke et al. (2006), which is normally used to estimate fractional cloud cover from incoming longwave radiation and air temperature. Relative humidity and wind speed data were used without alterations. Snow 


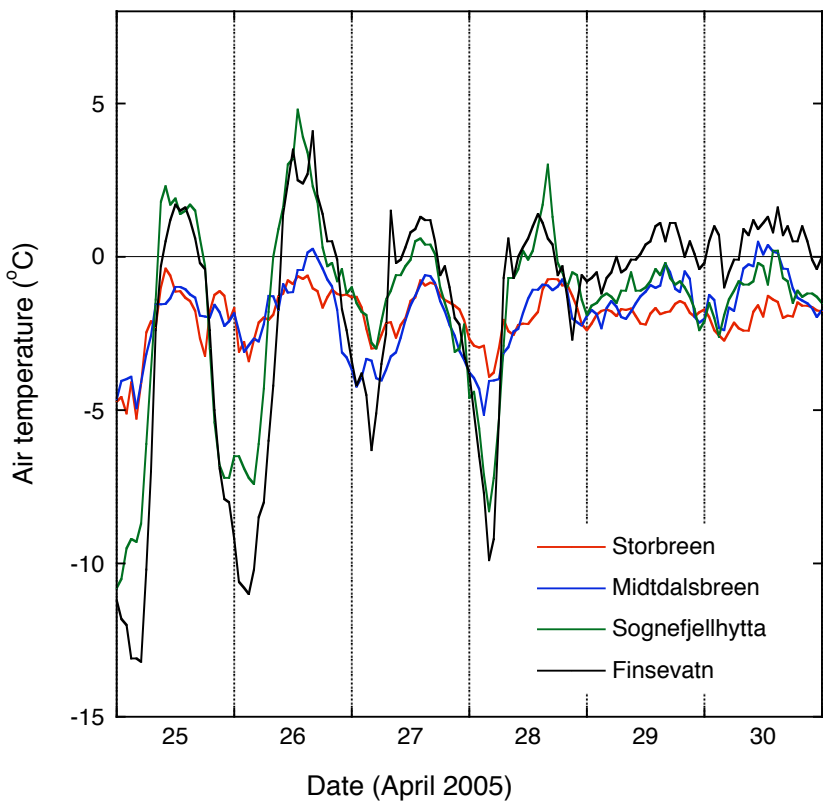

Fig. 13. Hourly air temperatures at Storbreen, Midtdalsbreen, Sognefjellhytta and Finsevatn on six days in April 2005.

depth and surface albedo are taken from the measurements, hence the positive feedback process of a possible change in ice reappearance date on net solar radiation is not included. The model has been run for Storbreen with data from Midtdalsbreen and Sognefjellhytta, for Midtdalsbreen we used data from Storbreen and Finsevatn.

Using relative humidity data from another location affects the modelled melt by less than $2 \%$. Applying air temperatures from the other glacier AWS also has a small effect. However, air temperatures extrapolated from Sognefjellhytta result in $11 \%$ more melt on Storbreen and using air temperatures from Finsevatn lead to an $8 \%$ increase in modelled melt on Midtdalsbreen. In spring, applying a different temperature record does not notably affect modelled melt, despite the large differences in the daily cycle. In summer, air temperatures on the glaciers are almost continuously overestimated using air temperatures from Sognefjellhytta and Finsevatn. The air above the glaciers is cooled by the relatively cold glacier surface and variable lapse rates should be applied. Using wind speeds measured on Midtdalsbreen in the energy balance calculations for Storbreen and vice versa induces the largest changes in modelled melt: a 17\% increase on Storbreen and a 13\% decrease on Midtdalsbreen. Wind speeds from Sognefjellhytta affect the melt on Storbreen by less than $1 \%$, while wind speeds from Finsevatn reduce melt on Midtdalsbreen by $9 \%$. Hence, on glaciers where the turbulent fluxes contribute significantly to the total melt, local wind speed and air temperature measurements are required for an accurate calculation of the surface energy balance. Energy balance models driven with data from outside the glacier boundary-layer need to be calibrated with measurements made on the glacier. Alternatively, an energy balance model including glacier boundary-layer processes could be applied (e.g. Denby, 1999).

\section{Conclusions}

We compared measurements made with two identical AWSs on Storbreen and Midtdalsbreen, two glaciers in southern Norway, $120 \mathrm{~km}$ apart. Except for wind speed and wind direction, daily mean values of all recorded variables exhibit simultaneous fluctuations of comparable magnitude. Especially daily mean air temperature is highly correlated $(r=0.98)$; the good correlation persists when the seasonal cycle is removed $(r=0.95)$. The average wind speed is a factor 1.75 higher on Midtdalsbreen than on Storbreen. The wind climate on Midtdalsbreen is mainly dominated by the large-scale circulation. On Storbreen, a katabatic wind develops regularly and determines the dominant wind direction. Katabatic winds are also observed on Midtdalsbreen, but less frequently, as wind speeds associated with the large-scale circulation are much higher. On Midtdalsbreen, westerly winds are dominant.

Incoming and net solar radiation are larger on Midtdalsbreen, due to a higher atmospheric transmissivity and an earlier disappearance of the snowpack than on Storbreen. In spring and summer, thicker clouds on Storbreen result in more positive incoming and net longwave radiation than on Midtdalsbreen. The turbulent fluxes are a factor 1.9 larger on Midtdalsbreen, mainly due to the larger wind speeds, but secondly because the air is slightly warmer and more humid.

On both glaciers net radiation is the largest contributor to surface melt, its relative contribution is larger on Storbreen (76\%) than on Midtdalsbreen (66\%). The importance of net radiation decreases over the melt season, while the turbulent fluxes become more important. Recorded snow depth at the two AWS sites generally shows simultaneous snowfall events of comparable magnitude. The larger surface energy fluxes on Midtdalsbreen result in a larger ablation rate and an earlier reappearance of the ice surface. The consequent drop in albedo further enhances the difference in ablation at the two glaciers; annual ice melt is $70 \%$ larger on Midtdalsbreen.

The absolute values and relative contributions of the surface energy fluxes to surface melt found for Storbreen and Midtdalsbreen lie within the range of values reported from energy balance studies performed on glaciers at comparable latitudes, although the contribution of net radiation for Storbreen is relatively large.

Recalculating the energy balance with meteorological variables measured outside the glacier boundary-layer shows that large errors originate when differences in variables caused by the glacier environment are not accounted for. Hence, an energy model driven with meteorological data measured outside the glacier needs to be calibrated with 

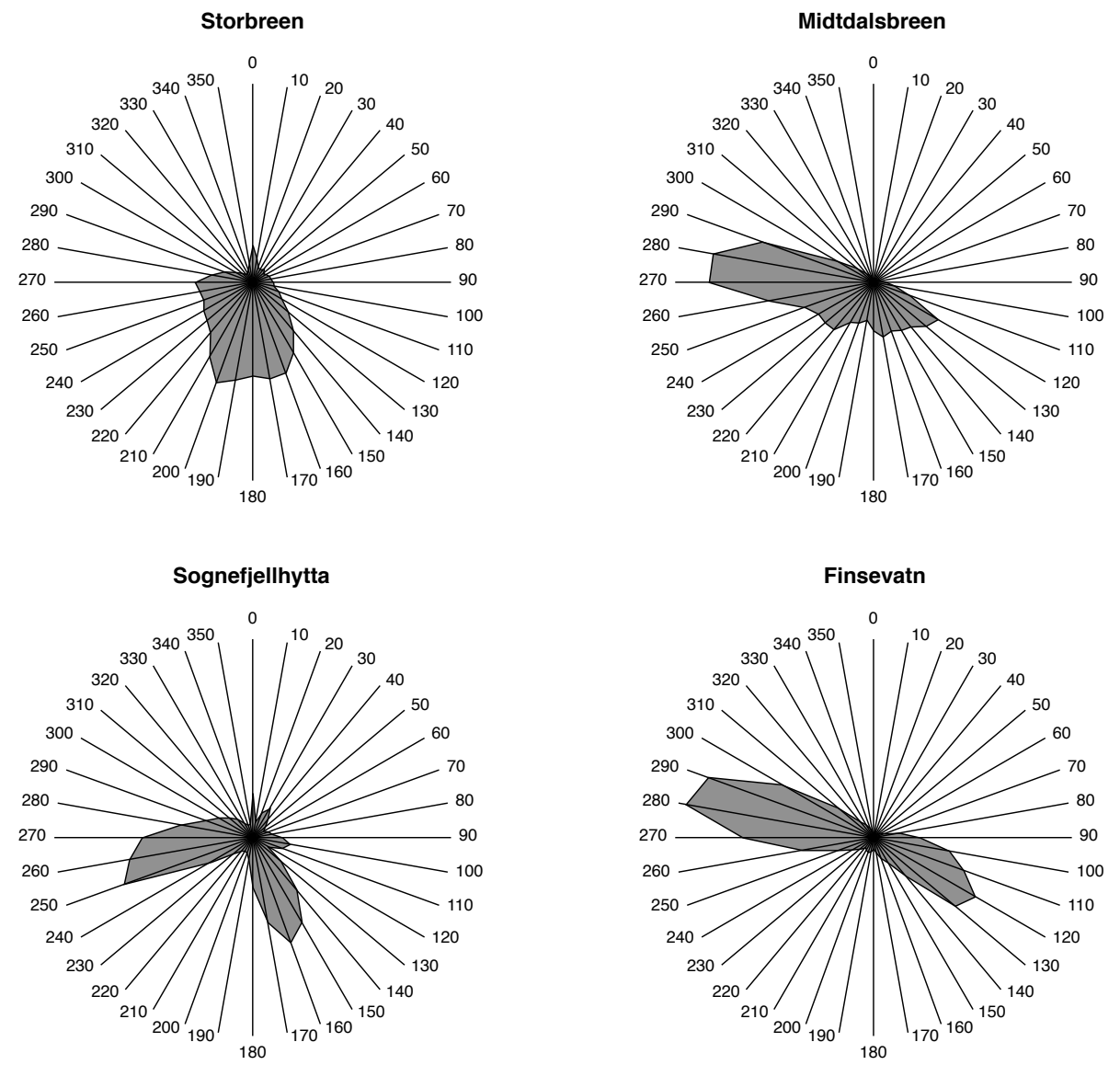

Fig. 14. Wind direction frequency distributions for Storbreen, Midtdalsbreen, Sognefjellhytta and Finsevatn, where all hourly intervals with measurements at all four stations are included (63\% of all hourly intervals).

measurements made on the glacier or should include a glacier-boundary layer model.

Acknowledgements. We thank the IMAU technicians, in particular Wim Boot, for the dedicated maintenance of the AWSs and several colleagues for their assistance in the field. The Norwegian Meteorological Institute is thanked for access to and use of their meteorological database eKlima. ECMWF ERA-40 and operational data used in this study have been provided by ECMWF. This project has been supported by NWO (Netherlands Organisation for Scientific Research) through the Spinoza-grant to J. Oerlemans.

\section{References}

Andreas, E. L.: A theory for the scalar roughness and the scalar transfer coefficients over snow and sea ice, Bound.-Lay. Meteorol., 38, 159-184, 1987.

Andreassen, L. M.: Comparing traditional mass balance measurements with long-term volume change extracted from topographical maps: a case study of Storbreen glacier in Jotunheimen, Norway, for the period 1940-1997, Geogr. Ann. A, 81, 467-476, 1999.
Andreassen, L. M., Elvehøy, H., Kjøllmoen, B., Engeset, R. V., and Haakensen, N.: Glacier mass-balance and length variation in Norway, Ann. Glaciol., 42, 317-325, 2005.

Andreassen, L. M., Van den Broeke, M. R., Giesen, R. H., and Oerlemans, J.: A 5 year record of surface energy and mass balance from the ablation zone of Storbreen, Norway, J. Glaciol., 54, 245-258, 2008.

Bintanja, R.: The local surface energy balance of the Ecology Glacier, King George Island, Antarctica: measurements and modelling, Antarct. Sci., 7, 315-325, 1995.

Braithwaite, R. J. and Olesen, O. B.: A simple energy-balance model to calculate ice ablation at the margin of the Greenland ice sheet, J. Glaciol., 36, 222-228, 1990.

Brazel, A. J., Tempe, F. B., Chambers, D., and Kalkstein, L. S.: Summer energy balance on West Gulkana Glacier, Alaska, and linkages to a temporal synoptic index, Z. Geomorphol. Suppl. Band, 86, 15-34, 1992.

Curry, J. A. and Webster, P. J.: Thermodynamics of atmospheres and oceans, Academic Press, San Diego, 1999.

Denby, B.: Second-order modelling of turbulence in katabatic flows, Bound.-Lay. Meteorol., 92, 65-98, 1999.

Dyer, A. J.: A review of flux-profile relationships, Bound.-Lay. Meteorol., 7, 363-372, 1974.

Fitzpatrick, M. F., Brandt, R. E., and Warren, S. G.: Transmission 
of solar radiation by clouds over snow and ice surfaces: a parameterization in terms of optical depth, solar zenith angle, and surface albedo, J. Climate, 17, 266-275, 2004.

Giesen, R. H., Van den Broeke, M. R., Oerlemans, J., and Andreassen, L. M.: The surface energy balance in the ablation zone of Midtdalsbreen, a glacier in southern Norway: Interannual variability and the effect of clouds, J. Geophys. Res., 113, D21111, doi:10.1029/2008JD010390, 2008.

Green, F. H. W. and Harding, R. J.: The altitudinal gradients of air temperature in southern Norway, Geogr. Ann. A, 62, 29-36, 1980.

Hock, R.: Glacier melt: a review of processes and their modelling, Prog. Phys. Geog., 29, 362-391, 2005.

Hock, R. and Holmgren, B.: Some aspects of energy balance and ablation of Storglaciären, Northern Sweden, Geogr. Ann. A, 78, 121-131, 1996.

Hogg, I. G. G., Paren, J. G., and Timmis, R. J.: Summer heat and ice balances on Hodges Glacier, South Georgia, Falkland Islands Dependencies, J. Glaciol., 28, 221-238, 1982.

Holtslag, A. A. M. and De Bruin, H. A. R.: Applied modeling of the nighttime surface energy balance over land, J. Appl. Meteorol., 27, 689-704, 1988.

Kjøllmoen, B., Andreassen, L. M., Elvehøy, H., Jackson, M., Tvede, A. M., Laumann, T., and Giesen, R. H.: Glaciological investigations in Norway in 2006, NVE Report No 1, Norwegian Water Resources and Energy Directorate, Oslo, 99 pp., 2007.

Klemsdal, T.: A glacio-meteorological study of Gråsubreen, Jotunheimen, in: Norsk Polarinstitutt - Årbok 1968, Norsk Polarinstitutt, Oslo, Norway, 58-74, 1970.

Klok, E. J., Nolan, M., and Van den Broeke, M. R.: Analysis of meteorological data and the surface energy balance of McCall Glacier, Alaska, USA, J. Glaciol., 51, 451-461, 2005.

Konya, K., Matsumoto, T., and Naruse, R.: Surface heat balance and spatially distributed ablation modelling at Koryto Glacier, Kamchatka peninsula, Russia, Geogr. Ann. A, 86A, 337-348, 2004.

Liestøl, O.: Storbreen Glacier in Jotunheimen, Norway, Norsk Polarinstitutt Skrifter Nr. 141, Norsk Polarinstitutt, Oslo, Norway, 63 pp., 1967.

Messel, S.: Mass and heat balance of Omnsbreen - a climatically dead glacier in southern Norway, Norsk Polarinstitutt Skrifter No. 156, Norsk Polarinstitutt, Oslo, Norway, 43 pp., 1971.

Messel, S.: Energibalanse-unders $\varnothing$ kelser på breer i Norge 19541981, in: Glasiologiske undersøkelser i Norge 1982, NVE rapport Nr. 1-85, edited by Roland, E. and Haakensen, N., Norwegian Water Resources and Energy Directorate, Oslo, Norway, 45-59, 1985.
Munro, D. S.: Comparison of melt energy computations and ablatometer measurements on melting ice and snow, Arctic Alpine Res., 22, 153-162, 1990.

Oerlemans, J.: Glaciers and Climate Change, Balkema, Lisse, 2001.

Ohmura, A.: Physical basis for the temperature-based melt-index method, J. Appl. Meteorol., 40, 753-761, 2001.

Schneider, C., Kilian, R., and Glaser, M.: Energy balance in the ablation zone during the summer season at the Gran Campo Nevado Ice Cap in the Southern Andes, Global Planet. Change, 59, 175188, 2007.

Streten, N. A. and Wendler, G.: The midsummer heat balance of an Alaskan maritime glacier, J. Glaciol., 7, 431-440, 1968.

Takeuchi, Y., Naruse, R., and Satow, K.: Characteristics of heat balance and ablation on Moreno and Tyndall glaciers, Patagonia, in the summer 1993/94, Bull. Glacier Res., 13, 45-56, 1995a.

Takeuchi, Y., Satow, K., Naruse, R., Ibarzabal, T., Nishida, K., and Matsuoka, K.: Meteorological features at Moreno and Tyndall glaciers, Patagonia, in the summer 1993/94, Bull. Glacier Res., 13, 35-44, 1995b.

Van den Broeke, M. R., Reijmer, C. H., and Van de Wal, R. S. W.: Assessing and improving the quality of unattended radiation observations in Antarctica, J. Atmos. Ocean. Tech., 21, 1417-1431, 2004.

Van den Broeke, M. R., Reijmer, C. H., Van As, D., Van de Wal, R. S. W., and Oerlemans, J.: Seasonal cycles of Antarctic surface energy balance from automatic weather stations, Ann. Glaciol., 41, 131-139, 2005.

Van den Broeke, M. R., Reijmer, C. H., Van As, D., and Boot, W.: Daily cycle of the surface energy balance in Antarctica and the influence of clouds, Int. J. Climatol., 26, 1587-1605, 2006.

Van den Broeke, M. R., Smeets, P., Ettema, J., and Kuipers Munneke, P.: Surface radiation balance in the ablation zone of the west Greenland ice sheet, J. Geophys. Res., 113, doi: 10.1029/2007JD009283, 2008a.

Van den Broeke, M., Smeets, P., Ettema, J., Van der Veen, C., Van de Wal, R., and Oerlemans, J.: Partitioning of melt energy and meltwater fluxes in the ablation zone of the west Greenland ice sheet, The Cryosphere, 2, 179-189, 2008b.

Wendler, G. and Streten, N. A.: A short term heat balance study on a coast range glacier, Pure Appl. Geophys., 77, 68-77, 1969.

Willis, I. C., Arnold, N. S., and Brock, B. W.: Effect of snowpack removal on energy balance, melt and runoff in a small supraglacial catchment, Hydrol. Process., 16, 2721-2749, 2002. 